ROBERT V. PERCIVAL

\title{
MASSACHUSETTS v EPA: ESCAPING THE COMMON LAW'S GROWING
}

\section{SHADOW}

In its first full Term with its newest member, the U.S. Supreme Court marched decidedly to the right with decisions narrowing abortion rights, striking down affirmative action programs, invalidating campaign finance regulations, and making it more difficult for victims of employment discrimination to seek redress. In the face of this rightward shift the most surprising decision of the Term was the Court's embrace of claims that the U.S. Environmental Protection Agency (EPA) had acted unlawfully by refusing to use the Clean Air Act to combat climate change. In Massachusetts $v$ EPA, ${ }^{1}$ the Court held that EPA had the authority to regulate emissions of greenhouse gases from motor vehicles under the Clean Air Act, and it ordered the agency to reconsider its refusal to do so.

The Court's decision vividly illustrates important features of its approach to regulatory issues today. The Court decided the case by a 5-4 margin, with Justices in the majority and dissent sharply

\footnotetext{
Robert V. Percival is the Robert F. Stanton Professor of Law and the Director of the Environmental Law Program at the University of Maryland School of Law.

Author's note: I would like to thank the members of the Georgetown Environmental Research Workshop, including Lisa Heinzerling, E. Donald Elliott, Richard Lazarus, and John Echeverria, for valuable comments on a previous draft of this article. I also would like to thank Maryland law students Gaddiel Baah, Julie Grufferman, and Elaine Lutz for research assistance.

${ }^{1} 127$ S Ct 1438 (2007).

(C) 2008 by The University of Chicago. All rights reserved.

978-0-226-36252-6/2008/2007-0003\$10.00
} 
disagreeing with each other on issues of constitutional law, statutory interpretation, and administrative law. As in each of the other twenty-three cases the Court decided by a single vote during this Term, Justice Kennedy cast the deciding vote. The ultimate lineup of the other eight Justices was entirely predictable. Justices Stevens, Souter, Ginsburg, and Breyer joined Kennedy in siding with the environmental plaintiffs, while Justices Scalia, Thomas, Chief Justice Roberts, and Justice Alito voted to uphold the agency's refusal to act.

At first glance Massachusetts $v$ EPA may seem to be a surprising green turn by the Court (one scholar called it "as close as we will come" to a "Brown v. Board of Education for the environment"). Environmental advocates hope it will spawn regulatory action to combat climate change; some anticipate a new flood of lawsuits against major sources of greenhouse gas emissions. While the decision is a profoundly important victory for environmentalists, lurking beneath its surface is a harsh reality: the decision confirms that the Justices are even more sharply split over foundational principles of the regulatory state than they were before the addition of the Court's two newest members.

Four Justices highly skeptical of environmental regulation narrowly construe regulatory statutes and seek to restrict citizen access to the courts to implement and enforce federal regulatory programs. Four other Justices are decidedly more sympathetic to the broad purposes of the environmental laws and the citizen suit provisions incorporated into them. Justice Kennedy is the man in the middleskeptical of regulation, but open to accommodating the orderly evolution of the modern regulatory state.

The struggle between these two camps echoes centuries-old tensions between the common law's skepticism of regulatory interventions by government and the civil law's greater tolerance for them. These tensions were most evident when U.S. courts heard early challenges to the New Deal's regulatory programs. Despite the rise of the modern regulatory state, these tensions frequently resurface as courts review regulatory decisions by administrative agencies. After describing this emerging pattern, this article examines how it is reflected in the sharp divisions between the majority and dissenting opinions in Massachusetts $v$ EPA. It then discusses

${ }^{2}$ Jonathan Z. Cannon, The Significance of Massachusetts v. EPA, Va L Rev In Brief 53 (May 21, 2007), online at http://www.virginialawreview.org/inbrief/2007/05/21/cannon.pdf. 
the implications of this decision for the struggle to overcome barriers to global, collective action to respond to climate change.

\section{The Growing Shadow of the Common Law on Judicial Review of Regulatory Decisions}

Before examining the Court's decision in Massachusetts $v$ $E P A$, it is important first to consider how the Court has evolved in its treatment of challenges to regulatory decisions. Prior to the enactment of comprehensive federal regulatory statutes, the common law of nuisance was the first line of legal defense for the environment. In the early decades of the twentieth century, the Supreme Court itself heard many prominent disputes between states over transboundary air and water pollution. ${ }^{3}$ When massive pollution from large sources, such as copper smelters, caused visible environmental harm, it was possible for plaintiffs to satisfy the common law's demands for individualized proof of causal injury. The U.S. Supreme Court issued injunctions to control pollution in several cases, though it did not relish performing the role of a national regulatory agency. The common law helped encourage noxious activities to locate away from populated areas, and it spurred the development of new technology to control pollution.

During the 1970s Congress enacted comprehensive regulatory legislation to protect the environment. The regulatory programs these new laws erected were designed to overcome the inadequacies of the common law in combating chronic, multisource pollution problems by giving expert administrative agencies the authority to adopt preventive regulations. Emphasizing the comprehensive nature of the regulatory scheme established by the Clean Water Act, the U.S. Supreme Court interpreted this law to supplant the federal common law of interstate nuisance. ${ }^{4}$

Courts reviewing the first generation of regulations implementing these programs confronted claims by regulated entities that agencies had adopted excessively burdensome regulations that would do little to protect human health and the environment. Responding to such claims, a plurality of the Supreme Court in 1980 invalidated an Occupational Safety and Health Administration

\footnotetext{
${ }^{3}$ See Robert V. Percival, The Clean Water Act and the Demise of the Federal Common Law of Interstate Nuisance, 55 Ala L Rev 717, 717 n 4 (2004).

${ }^{4}$ City of Milwaukee v Illinois, 451 US 304 (1981).
} 
(OSHA) regulation to protect workers against exposure to benzene. ${ }^{5}$ By creative interpretation of a definitional provision in the Occupational Safety and Health (OSH) Act, the plurality imposed new preconditions on agency issuance of regulations. OSHA was directed to perform a risk assessment to determine if current levels of workplace exposure to benzene posed a "significant risk" and to ascertain that such a risk could be appreciably reduced by regulation. For a plurality decision interpreting a single statute, Benzene had a surprisingly large impact as agencies operating under a plethora of regulatory authorities routinely began to conduct risk assessments. However, the Court quickly signaled that it would not hamstring preventive regulation when it rejected industry efforts to write a cost-benefit analysis requirement into the OSH Act. ${ }^{6}$

Despite Benzene, reviewing courts generally were not hostile to the first generation of federal environmental, health, and safety regulations. Three years after Benzene, the Court's Chevron decision ${ }^{7}$ directed reviewing courts to give greater deference to reasonable agency interpretations of ambiguous statutory provisions. While Chevron (and Vermont Yankee — a decision giving agencies more procedural freedom) reversed victories by environmental groups in the Courts of Appeals, the Supreme Court was not on a mission to tilt judicial review in an antiregulatory direction. This was confirmed by its State Farm decision ${ }^{9}$ where the Court required the National Highway Transportation Safety Administration (NHTSA) to reconsider its decision to rescind a regulation requiring motor vehicles to employ passive restraints to reduce deaths in auto accidents.

A key feature of the new regulatory legislation was its authorization for citizen suits to enforce regulations and to require agencies to perform nondiscretionary duties. The courts facilitated such actions by recognizing that aesthetic injury could give rise to standing to sue by environmental interests. While disappointing environmentalists by rejecting the Sierra Club's efforts to establish auto-

\footnotetext{
${ }^{5}$ Industrial Union Department, AFL-CIO v American Petroleum Institute, 448 US 607 (1980) ("Benzene").

${ }^{6}$ American Textile Manufacturers Institute v Donovan, 452 US 490 (1981).

${ }^{7}$ Chevron, USA v Natural Resources Defense Council, 467 US 837 (1984).

${ }^{8}$ In Vermont Yankee Nuclear Power Corp. v Natural Resources Defense Council, 435 US 519 (1978), the Court directed lower courts not to impose additional procedural requirements on agencies that go beyond requirements contained in the underlying regulatory statute.

${ }^{9}$ Motor Vebicle Manufacturers Ass'n v State Farm Mutual Auto. Insur. Co., 463 US 29 (1983).
} 
matic standing, the Supreme Court's decision in Sierra Club v Mor$t o n^{10}$ established that allegations of aesthetic injury could give rise to standing and that "the fact that particular environmental interests are shared by the many rather than the few does not make them less deserving of legal protection through the judicial process." ${ }^{11}$ The following year the Court upheld the standing of a student group to challenge a railroad tariff that allegedly would reduce the market for recycled materials in United States $v$ Students Challenging Regulatory Agency Procedures (SCRAP). ${ }^{12}$ The Court reiterated not only that aesthetic and environmental harm could give rise to standing, but also that "standing is not to be denied simply because many people suffer the same injury." "As Justice Stewart explained in his opinion for the Court: "To deny standing to persons who are in fact injured simply because many others are also injured, would mean that the most injurious and widespread Government actions could be questioned by nobody. We cannot accept that conclusion." 14

While the Supreme Court generally was not viewed as a champion of environmental interests when it was under the leadership of Chief Justice Burger, in a number of decisions it did not hesitate to read the new federal regulatory statutes broadly. This is illustrated by the Court's landmark 1978 "snail darter" decision interpreting the Endangered Species Act ${ }^{15}$ and its unanimous 1985 decision upholding regulations applying the Clean Water Act to wetlands adjacent to navigable waters. ${ }^{16}$ In addition to broadly interpreting the scope of federal regulatory authority to achieve the ambitious goals of the Acts, the Court emphasized the importance of deferring to agency expertise. Thus in Riverside Bayview, Justice White writing for a unanimous Court stated:

In view of the breadth of federal regulatory authority contemplated by the Act itself and the inherent difficulties of defining precise bounds to regulable waters, the Corps' ecological judg-

\footnotetext{
${ }^{10} 405$ US 727 (1972).

${ }^{11} \mathrm{Id}$ at 734 .

${ }^{12} 412$ US 669 (1973).

${ }^{13} \mathrm{Id}$ at 687.

${ }^{14} \mathrm{Id}$ at 688 .

${ }^{15}$ Tennessee Valley Authority v Hill, 437 US 153 (1978).

${ }^{16}$ United States v Riverside Bayview Homes, Inc., 474 US 121 (1985).
} 
ment about the relationship between waters and their adjacent wetlands provides an adequate basis for a legal judgment that adjacent wetlands may be defined as waters under the Act. ${ }^{17}$

The Court today is sharply split on its approach to review of environmental regulations. After William Rehnquist became Chief Justice and Antonin Scalia joined the Court in 1986, the Court became more solicitous of private property rights and more skeptical about environmental standing. In each area of law, the Justices championing this shift reimported common law principles to judicial review of regulatory decisions. In a law review article written three years before he joined the Court, ${ }^{18}$ Justice Scalia boldly revealed his antipathy to environmental standing based on his ideological distaste for strict implementation of the environmental laws. In 1992, he authored both the Court's most restrictive environmental standing decision (Lujan $)^{19}$ and a landmark property rights decision (Lucas).$^{20}$ In the former Justice Scalia questioned the constitutional authority of Congress to authorize certain citizen suits, while in the latter he dismissed state legislative findings concerning what activities pose a danger to public health and the environment. Elevating common law principles to constitutional status, he declared in Lucas that regulations that deprive real property of all economically viable use require payment of just compensation unless they proscribe only activities that would be nuisances prohibited at common law. Justice Scalia insisted in Lucas that legislative findings that regulation is necessary to prevent environmental harm are insufficient in themselves to preclude takings liability. Instead the Court held that only regulations forbidding activities that were common law nuisances at the time the Constitution was adopted could qualify for the nuisance exception to takings liability. Signaling his openness to a more flexible approach to applying common law notions, Justice Kennedy in a concurring opinion expressed his discomfort with Justice Scalia's approach. Justice Kennedy concluded that "nuisance prevention" is not the "sole source of state authority to impose severe restrictions" given the state's interest in

\footnotetext{
${ }^{17} \mathrm{Id}$ at 134 .

${ }^{18}$ Antonin Scalia, The Doctrine of Standing as an Essential Element of the Separation of Powers, 17 Suffolk U L Rev 881 (1983).

${ }^{19}$ Lujan v Defenders of Wildlife, 504 US 555 (1992).

${ }^{20}$ Lucas v South Carolina Coastal Council, 505 US 1003 (1992).
} 
"enacting new regulatory initiatives in response to changing conditions ....."21

In another property rights case decided two years later, the Court limited the ability of government authorities to seek regulatory exactions from developers. It required that the government demonstrate not only an "essential nexus" between the state interest and nature of the exaction, ${ }^{22}$ but also that the magnitude of the exaction is "roughly proportional" to the impact of the development. ${ }^{23}$ In similar fashion, the Court in City of Boerne $v$ Flores ${ }^{24}$ considerably limited the remedial powers Congress may exercise under Section 5 of the Fourteenth Amendment by requiring that it show "congruence and proportionality" between its legislative goals and the prevention of actual violations of Fourteenth Amendment rights. In each of these cases, the Court constructed its own type of common law demonstration of injury that the government must satisfy before its regulatory action can be upheld.

While the Burger Court's environmental decisions did not feature ideologically predictable coalitions of Justices on either side, the Rehnquist Court's decisions were a different matter, particularly after the Court embarked on its campaigns to revive constitutional limits on federal power, to vindicate state sovereignty, and to strengthen constitutional protection for property rights. Most of these cases were decided by a stable coalition of five Justices over strident dissents by the other four members of the Court. Prominent features of these decisions included the majority's profound distrust of legislative findings of harm and its insistence on more demanding demonstrations of causal connections between regulated activities and the harm the regulation seeks to prevent.

For example, in United States $v$ Lopez ${ }^{25}$ the Court held by a 5-4 majority that the Commerce Clause did not give Congress the authority to prohibit the possession of firearms in the vicinity of schools because the statute at issue regulated an activity that did not "substantially affect" interstate commerce. The five-Justice majority in Lopez emphasized that Congress had not made factual

\footnotetext{
${ }^{21}$ Id at 1035 (Kennedy concurring).

${ }^{22}$ This requirement was first established in Nollan v California Coastal Commission, 483 US 825 (1987).

${ }^{23}$ Dolan v City of Tigard, 512 US 374 (1994).

${ }^{24} 521$ US 507 (1997).

${ }^{25} 514$ US 549 (1995).
} 
findings concerning the impact of firearm possession near schools on interstate commerce. However, five years later in United States $v$ Morrison $^{26}$ it invalidated legislation creating a federal civil cause of action for victims of gender-motivated violence, despite the fact that Congress had made extensive findings concerning the substantial impact of such violence on interstate commerce.

Even when the Rehnquist Court rebuffed efforts to narrow the scope of the environmental laws through judicial interpretation, some Justices sought to fashion implied common law limits on their application. In Babbitt $v$ Sweet Home Chapter of Communities for a Great Oregon ${ }^{27}$ the Court reversed a lower court's interpretation of the Endangered Species Act that limited its prohibition on "taking" endangered species to embrace only the direct physical application of force. The Court upheld regulations that also barred the destruction of the species' critical habitat if it caused harm to their members. Justice O'Connor wrote a separate concurring opinion arguing that common law principles of proximate cause necessarily limit application of this provision. ${ }^{28}$

Both Justice O'Connor and Chief Justice Rehnquist abandoned Justice Scalia's campaign to restrict environmental standing in 2000 when they joined five other Justices in upholding the standing of citizens living near a company that repeatedly violated the Clean Water Act to sue to enforce permit limits. ${ }^{29}$ The decision emphasized that plaintiffs need not demonstrate that the permit violations had caused actual harm to the environment, but rather only that they caused the plaintiffs to have reasonable concerns about the impact of the violations. The following year the Court unanimously upheld the constitutionality of the Clean Air Act, rejecting an industry challenge premised on the long dormant nondelegation doctrine. ${ }^{30}$

While rebuffing most constitutional challenges to environmental regulation, the Rehnquist Court cited constitutional concerns in construing the scope of the environmental laws more narrowly. In 2001, the Court in Solid Waste Agency of Northern Cook County $v$ U.S. Army Corps of Engineers (SWANCC) held that the Clean Water

\footnotetext{
${ }^{26} 529$ US 598 (2000).

${ }^{27} 515$ US 687 (1995).

${ }^{28}$ Id at $708-09$.

${ }^{29}$ Friends of the Earth v Laidlaw Environmental Services, 528 US 167 (2000).

${ }^{30}$ Whitman v American Trucking Associations, 531 US 457 (2001).
} 
Act did not authorize the regulation of dredge and fill activities in isolated wetlands. ${ }^{31}$ The Court's 5-4 majority declined to reach the constitutional issue because it found that Congress had not intended to allow the Corps to regulate isolated wetlands. Stating that it expected a clear statement of Congressional intent to support "an administrative interpretation of a statute [that] invokes the outer limits of Congress' power," ${ }^{32}$ the Court majority concluded that regulation of isolated wetlands exceeded the Corps' authority under the Act. $^{33}$

The sharp division in the Court concerning the scope of the Clean Water Act was further illustrated the next year when the Court split 4-4 in a wetlands case in which Justice Kennedy had recused himself. ${ }^{34}$ But it was only after Chief Justice Rehnquist's death and the confirmation of Chief Justice Roberts that the full dimensions of the Court's divisions became most apparent. In 2006 the Court split 4-1-4 in deciding whether the Clean Water Act could be applied to wetlands adjacent to nonnavigable tributaries of navigable waters. ${ }^{35}$

In an opinion authored by Justice Scalia, a plurality of four Justices (including Chief Justice Roberts, Justice Thomas, and Justice Alito) endorsed a radically restrictive interpretation of "waters of the United States" that would have significantly narrowed the scope of federal jurisdiction under the Clean Water Act had it commanded a majority of the Court. ${ }^{36}$ While rejecting the petitioners' argument that the Act applies only to waters navigable in fact or susceptible of being so rendered, the plurality relied on a 1954 dictionary definition of "waters" to conclude that it includes "only relatively permanent, standing or flowing bodies of water." " Addressing the difficulty of squaring this conclusion with the Court's unanimous holding in Riverside Bayview, the plurality creatively explained "Riverside Bayview rested upon the inherent ambiguity in

${ }^{31}$ Solid Waste Agency of N. Cook County v U.S. Army Corps of Engineers, 531 US 159 (2001).

${ }^{32} \mathrm{Id}$ at 172.

${ }^{33}$ Id at 174 .

${ }^{34}$ Borden Ranch Partnership v U.S. Army Corps of Engineers, 261 F3d 810 (9th Cir 2001), aff'd by an equally divided Court, 537 US 99 (2002).

${ }^{35}$ Rapanos v United States, 126 S Ct 2208 (2006).

${ }^{36} \mathrm{Id}$.

${ }^{37}$ Id at $2220-21$. 
defining where water ends and abutting ('adjacent') wetlands begin, permitting the Corps' reliance on ecological considerations only to resolve that ambiguity in favor of treating all abutting wetlands as waters." 38

In an opinion authored by Justice Stevens, four dissenting Justices (including Justices Souter, Ginsburg, and Breyer) argued that federal Clean Water Act jurisdiction extends to wetlands adjacent to nonnavigable tributaries of navigable waters. They argued that the case was squarely controlled by the Court's unanimous decision in Riverside Bayview and that contrary interpretations were inconsistent with the legislative history and purposes of the Clean Water Act.

The Army Corps has determined that wetlands adjacent to tributaries of traditionally navigable waters preserve the quality of our Nation's waters by, among other things, providing habitat for aquatic animals, keeping excessive sediment and toxic pollutants out of adjacent waters, and reducing downstream flooding by absorbing water at times of high flow. The Corps' resulting decision to treat these wetlands as encompassed within the term "waters of the United States" is a quintessential example of the Executive's reasonable interpretation of a statutory provision. ${ }^{39}$

Neither of these opinions commanded a majority of the Court because the decisive ninth vote was cast by Justice Kennedy who wrote an opinion concurring only in the judgment that the decision below should be reversed and the case remanded to the lower court. Justice Kennedy sharply rejected the radical narrowing of the Act advocated in the Scalia plurality opinion, and he acknowledged the importance of broadly protecting wetlands. While he agreed with much of the dissent, he supported a remand because he wanted the court below to apply a new standard he articulated in his concurrence. Justice Kennedy concluded that "to constitute 'navigable waters' under the Act, a water or wetland must possess a 'significant nexus' to waters that are or were navigable in fact or that could reasonably be so made." ${ }^{40}$ Thus, in Justice Kennedy's view, to successfully assert federal jurisdiction under the Act the government must show that "the wetlands, either alone or in combination with similarly situated lands in the region, significantly affect the chem-

\footnotetext{
${ }^{38} \mathrm{Id}$ at 2226 (emphasis in original).

${ }^{39}$ Id at 2252 (Stevens dissenting).

${ }^{40} \mathrm{Id}$ at 2236 (Kennedy concurring in the judgment).
} 
ical, physical, and biological integrity of other covered waters more readily understood as "navigable."' 14 He noted that if the effects are only "speculative or insubstantial" the wetlands will not be subject to federal jurisdiction, but he concluded that a "reasonable inference of ecologic interconnection" can be drawn for wetlands adjacent to navigable waters.

Because he cast the decisive vote in the case, Justice Kennedy's view of the applicable law now appears to be controlling even though it was rejected by all eight of the other Justices. Justice Kennedy himself emphatically rejected the view of the four-Justice plurality opinion authored by Justice Scalia. He argued that the limitations it seeks to impose on federal jurisdiction "are without support in the language and purposes of the Act or in our cases interpreting it." $42 \mathrm{He}$ explained that the "plurality's first requirement-permanent standing water or continuous flow, at least for a period of 'some months'-makes little practical sense in a statute concerned with downstream water quality" 43 and has no support in the statutory text even when dictionary definitions of "waters" are applied. Justice Kennedy argued that "exclusion of wetlands lacking a continuous surface connection to other jurisdictional waters-is also unpersuasive" because wetlands are not "indistinguishable' from waters to which they bear a surface connection." cluded that "the plurality's opinion is inconsistent with the Act's text, structure, and purpose. $" 45$

Justice Kennedy and the four dissenting Justices also rejected the plurality's notion that federal jurisdiction should be interpreted narrowly to avoid constitutional concerns. Justice Kennedy noted that thirty-three states and the District of Columbia filed an amicus brief supporting a broad interpretation of federal jurisdiction because it "protects downstream States from out-of-state pollution that they cannot themselves regulate."46

Addressing the administrative difficulties of applying his "substantial nexus" approach to defining federal jurisdiction, Justice Kennedy suggested that:

\footnotetext{
${ }^{41}$ Id at 2248.

${ }^{42}$ Id at 2242.

${ }^{43}$ Id (citation omitted).

${ }^{44}$ Id at 2244.

${ }^{45}$ Id at 2246.

${ }^{46} \mathrm{Id}$.
} 
[t]hrough regulations or adjudication, the Corps may choose to identify categories of tributaries that, due to their volume of flow (either annually or on average), their proximity to navigable waters, or other relevant considerations, are significant enough that wetlands adjacent to them are likely, in the majority of cases, to perform important functions for an aquatic system incorporating navigable waters. ${ }^{47}$

For wetlands adjacent to navigable-in-fact waters, Justice Kennedy concluded that adjacency can be sufficient for the Corps to establish jurisdiction. "Absent more specific regulations, however, the Corps must establish a significant nexus on a case-by-case basis when it seeks to regulate wetlands based on adjacency to nonnavigable tributaries." ${ }^{48}$ Justice Kennedy states that "[w]here an adequate nexus is established for a particular wetland, it may be permissible, as a matter of administrative convenience or necessity, to presume covered status for other comparable wetlands in the region." ${ }^{49}$

For now, the end product of Rapanos is that the scope of federal jurisdiction under the Clean Water Act is hopelessly confused. In an unusual concurring opinion, Chief Justice Roberts described the result of the 4-1-4 split as "unfortunate" because "no opinion commands a majority of the Court on precisely how to read Congress' limits on the reach of the Clean Water Act." ${ }^{, 50}$ As a result, he noted, "Lower courts and regulated entities will now have to feel their way on a case-by-case basis." ${ }^{51}$ Surprisingly, he suggested that the situation "readily . . . could have been avoided" if the Army Corps of Engineers had issued new regulations after $S W A N C C$ clarifying the limits of its jurisdictional reach. Citing Chevron, the Chief Justice noted "Given the broad, somewhat ambiguous, but nonetheless clearly limiting terms Congress employed in the Clean Water Act, the Corps and the EPA would have enjoyed plenty of room to operate in developing some notion of an outer bound to the reach of their authority." 52 Yet because the Chief Justice joined in full Justice Scalia's plurality opinion, which rejected any deference to a broader definition of "waters of the United States" than the one

\footnotetext{
${ }^{47}$ Id at 2248.

${ }^{48}$ Id at 2249.

${ }^{49} \mathrm{Id}$.

${ }^{50} \mathrm{Id}$ at 2236 (Roberts concurring).

${ }^{51} \mathrm{Id}$.

${ }^{52}$ Id.
} 
articulated by Justice Scalia, the Chief Justice's concurrence contributes further to the confusion.

While purporting to interpret Congressional intent, the opinions of the Justices in Rapanos reflect the more fundamental split that permeates much of the Court's jurisprudence in reviewing regulatory decisions by administrative agencies. ${ }^{53}$ Four Justices (Justices Scalia, Thomas, Chief Justice Roberts, and Justice Alito) join an opinion expressing extreme hostility to a long-standing regulatory interpretation (referring to it as a thirty-year-old "entrenched executive error" and stating that it "would authorize the Corps to function as a de facto regulator of immense stretches of intrastate land - an authority the agency has shown its willingness to exercise with the scope of discretion that would befit a local zoning board"). ${ }^{54}$ Four other Justices (Justices Stevens, Souter, Ginsburg, and Breyer) vote to uphold the regulation because they are willing to defer to the judgment of a federal agency that it is essential to achieving the Congressional purpose. The Justice in the middle-Justice Kennedy-acknowledges the importance of the regulatory goal while seeking to impose new procedural requirements on the agency to avoid overreaching.

Justice Scalia's group of Justices made highly exaggerated claims that $\$ 404$ imposes high costs on landowners while appearing dismissive of the ecological costs of filling wetlands. Justice Kennedy correctly calls Scalia's opinion "unduly dismissive" of the "[i]mportant public interests . . . served by the Clean Water Act in general and by the protection of wetlands in particular." ${ }^{55}$ In a footnote Justice Stevens criticizes the plurality's "antagonism to environmentalism" and its claim that his dissent is "policy-laden" by observing that " $[\mathrm{t}]$ he policy considerations that have influenced my thinking are Congress' rather than my own." ${ }^{56}$ This debate illustrates the sharply contrasting views concerning the value of federal regulatory programs to protect the environment among the Justices currently on the Court.

While four Justices readily accept the importance of legislation

\footnotetext{
${ }^{53}$ For a more detailed discussion contrasting the precautionary and reactive approaches to environmental regulation embraced by different members of the judiciary, see Robert V. Percival, Environmental Law in the Twenty-First Century, 25 Va Envir L J 1, 9-18 (2007).

${ }^{54}$ Rapanos, $126 \mathrm{~S}$ Ct at 2232, 2224 (Scalia plurality opinion).

${ }^{55}$ Id at 2246 (Kennedy concurring in the judgment).

${ }^{56} \mathrm{Id}$ at 2259 n 8 (Stevens dissenting).
} 
authorizing precautionary regulation, four others are reluctant to accept legislative findings to justify regulation and narrowly construe the scope and purposes of federal regulatory programs to protect the environment, even though the comprehensiveness of these programs was the Court's initial rationale for supplanting the federal common law of nuisance. Four Justices (Chief Justice Roberts and Justices Scalia, Thomas, and Alito) insist on more demanding, and more individualized, factual showings of causal connections before federal regulations are upheld or enforced, while four other Justices (Stevens, Souter, Ginsburg, and Breyer) are more tolerant of regulatory decisions founded on assessments of risk at the wholesale level.

This split reflects fundamental differences in the Justices' attitudes toward precautionary regulation. One group of Justices (Stevens, Souter, Ginsburg, and Breyer) is inclined to interpret the environmental statutes to facilitate achievement of their precautionary purposes by upholding regulation of activities believed to contribute to environmental harm. Another group of Justices (Scalia, Thomas, C. J. Roberts, and Alito) is profoundly skeptical of precautionary regulation and concerned about its cost and fairness. Even though regulatory legislation was adopted in response to the perceived inadequacies of the common law (particularly its demand for individualized proof of causal injury), these Justices insist on a kind of common law standard of proof connecting activities to be regulated with demonstrated environmental harm. This split permeates a wide range of decisions concerning who has standing to sue in environmental cases, the scope of federal regulatory authority, and even what constitutes a regulatory taking.

Justice Kennedy straddles both camps. He demands a greater showing of causal injury to justify regulation than the more precautionary group of Justices, but he also recognizes that " $t]$ he common law of nuisance is too narrow a confine for the exercise of regulatory power in a complex and interdependent society." ${ }^{157}$ While Justices Scalia and Thomas seek to keep environmental plaintiffs out of court on constitutional grounds, questioning whether citizen suits violate separation of powers principles, Justice Kennedy opines that the purchase of a plane ticket to visit foreign endangered species would have been enough to give an environmental group standing

\footnotetext{
${ }^{57}$ Lucas v South Carolina Coastal Commission, 505 US 1003, 1035 (1992) (Kennedy concurring in the judgment).
} 
in Lujan $v$ Defenders of Wildlife. ${ }^{58}$ While rejecting Justice Scalia's disdainfully narrow interpretation of the scope of the Clean Water Act in Rapanos $v$ United States, ${ }^{59}$ Justice Kennedy still insists on the government showing a "significant nexus" between wetlands it seeks to regulate and navigable waters. This produced the 4-1-4 split in Rapanos that has caused enormous confusion concerning the scope of federal authority under the Clean Water Act because Justice Kennedy's view of the applicable law now appears to be controlling even though it was rejected by all eight of the other Justices.

The Rapanos decision starkly highlights the differences between a precautionary approach to regulatory policy and a reactive one. The four Justices who voted to uphold federal regulation in the case were willing to defer to the judgment of a federal agency that it is essential to regulate wetlands adjacent to tributaries of navigable waters in order to prevent degradation of water quality. The four Justices who voted against the government were skeptical that such regulation would prevent ecological harm, but also fearful that this approach would allow federal agencies to regulate virtually anything. The influence of common law notions of causation is apparent in Justice Kennedy's approach, which acknowledges the importance of precautionary regulation, while insisting on some factual demonstration that regulated activities are connected to substantial environmental harm. No decision highlights so sharply the differences between the Justices in their approaches to judicial review of environmental regulations than Rapanos.

The sharp split between the Justices in their attitudes toward regulatory policy is strikingly similar to centuries-old debates between common law and civil law approaches to protection of public health, as Professor Noga Morag-Levine has demonstrated. ${ }^{60}$ Her research traces the evolution of judicial hostility in England toward continental Europe's "civil law model" that "relied on centralized, agency-based, state administration aimed at the implementation of regulatory standards through expert legislators and bureaucrats." ${ }_{11}$ By contrast, the "common law model fundamentally distrusted bu-

${ }^{58} 504$ US 555, 579 (1992) (Kennedy concurring in part and concurring in the judgment).

${ }^{59} 126$ S Ct 2208, 2248 (2006).

${ }^{60}$ Noga Morag-Levine, Common Law, Civil Law, and the Administrative State: EarlyModern England to the Lochner Era, Const Comm (forthcoming), online at http://ssrn.com/ abstract $=1031229$.

${ }^{61}$ Id (manuscript at 4). 
reaucratic administration, and as a consequence, identified courts as the proper locus of administrative governance." ${ }^{2}$ This controversy persisted throughout nineteenth-century U.S. debates over exercise of the police power. Proponents of the common law approach favored it because it "gave precedence to the communal norms and lay knowledge that juries could bring to regulatory decisions and the specialized knowledge of legally-trained judges." ${ }^{\prime 3}$ Nineteenth-century English nuisance cases were tried before juries who expressed the sense of the community concerning what enterprises caused too much environmental harm to be located near populated areas. ${ }^{64}$ With the shift away from the common law toward the administrative state as a vehicle for protecting public health and the environment, it no longer appears obvious that the common law is more protective of communal norms than precautionary regulation.

\section{The Massachusetts v EPA Decision}

Massachusetts $v$ EPA came before the Court the Term after it split so badly in Rapanos. The case originated in October 1999 when a group of public interest organizations filed a petition asking EPA to regulate emissions of greenhouse gases from new motor vehicles under $\$ 202$ of the Clean Air Act. When the petition was filed, no one would have predicted that it ultimately would spawn a monumental Supreme Court decision. Petitions for rulemaking often languish unanswered, and it was only after a lawsuit filed in December 2002 to compel a response was settled by EPA agreeing to respond to the petition that the agency denied it in September $2003 .{ }^{65} \mathrm{EPA}$ argued that it did not have the authority to regulate greenhouse gas emissions under the Clean Air Act and that even if it had such authority it would choose not to exercise it.

EPA's denial of the petition was challenged in the U.S. Court of Appeals for the D.C. Circuit by the public interest groups joined

\footnotetext{
${ }^{62} \mathrm{Id}$.

${ }^{63} \mathrm{Id}$.

${ }^{64}$ An illustration of this is the prosecution in April 1838 of James Muspratt for maintaining an alkali works in Liverpool. The case was tried before a special jury of twelve merchants who, following a three-day trial, found the defendant guilty of creating and maintaining a nuisance within the borough. A copy of the original trial transcript is available in the rare book collection of the Harvard Law School Library.

${ }^{65} 68$ Fed Reg 52922 (Sept 8, 2003).
} 
by twelve states, the territory of American Samoa, and the cities of Baltimore and New York City. A three-judge panel of that court split sharply in upholding EPA's decision by a $2-1$ vote. ${ }^{66}$ Judge Sentelle concluded that because the harm alleged from global warming was so widespread it did not constitute the kind of "particularized injuries" that could give the petitioners standing to challenge EPA's decision. Without specifically deciding the questions of standing and statutory authority, Judge Randolph concluded that EPA had acted properly in denying the petition. Judge Tatel dissented, concluding that the petitioners had standing, that EPA had the authority to regulate emissions of greenhouse gases under the Clean Air Act, and that EPA had not adequately justified its denial of the petition.

While the inability of the D.C. Circuit panel to muster a majority on any particular rationale for upholding EPA's denial of the petition left its decision a confused muddle, few expected the Supreme Court to agree to review it. Not only was there no circuit conflict, but there was no possibility of one developing in the future because the Clean Air Act gives the D.C. Circuit exclusive venue to review EPA decisions of national applicability. ${ }^{67}$ Nevertheless, the Supreme Court agreed to review the D.C. Circuit's decision.

When the Court issued its decision in April 2007, no one was surprised that the case was decided by a 5-4 vote of the Justices, though the ultimate outcome was surprising to many. In the course of deciding to reverse EPA's decision not to regulate emissions of greenhouse gases under the Clean Air Act, the Court addressed constitutional principles of standing to sue, interpreted the Clean Air Act, and applied principles of administrative law to reject EPA's rationale for failing to act as arbitrary and capricious. The Court held: (1) that the harm projected from global warming and climate change gives Massachusetts standing to sue even if the harm is widely shared and EPA can do little to alleviate most of it, (2) that the Clean Air Act gives EPA the authority to regulate greenhouse gas emissions, and (3) that EPA is required to regulate such emissions unless it determines that they do not contribute to climate change or the agency provides a reasonable explanation of why it cannot or will not determine whether they do.

\footnotetext{
${ }^{66}$ Massachusetts v EPA, 415 F3d 50 (DC Cir 2005).
}

${ }^{67} 42$ USC $\$ 7607(\mathrm{~b})(1)(2000)$. 
At a most basic level the result in Massachusetts $v$ EPA is easy to understand: Justice Kennedy, the only "swing" Justice now on the Court, sided with the four liberal/moderate Justices (Stevens, Souter, Ginsburg, and Breyer) instead of the four conservatives (Scalia, Thomas, C. J. Roberts, and Alito).$^{68}$ More than one-third of all the Court's decisions in its 2006 Term were the product of 5-4 votes and Justice Kennedy was in the majority in all twenty-four of those cases. Justice Stevens's majority opinion in the case shows signs of an attempt to court Justice Kennedy by extensively quoting from Justice Kennedy's concurring opinion in Lujan $v$ Defenders of Wildlife.

In his majority opinion Justice Stevens concluded that states have a special interest in protecting their land and citizens from environmental harm and that it is not necessary for EPA regulations to redress most of the harm for a state to have standing. He concluded that the Clean Air Act was meant to be a comprehensive regulatory scheme that requires EPA to control air pollutants that pose significant risks to the environment.

Justice Stevens's majority opinion spawned passionate dissents from Chief Justice Roberts and Justice Scalia. The Chief Justice argued that the effects of global warming are too generalized, too uncertain, and too unlikely to be effectively redressed by domestic regulation to provide any plaintiff with standing to sue. Justice Scalia argued for deference to EPA's decisions that it has no authority to regulate greenhouse gases and that it would not exercise such authority even if it had it. He endorsed the notion that greenhouse gases are not covered by the text of the Clean Air Act because "pollutants" are only substances that foul the air near the surface of the earth.

\section{A. STANDING TO SUE}

One surprise in Massachusetts $v E P A$ is the ease with which the majority dispatched concern about the states' standing to sue. The Court upheld the states' standing by reaching back to a centuryold precedent not cited by any of the parties to the case-Georgia $v$ Tennessee Copper Company. ${ }^{69}$ At oral argument Justice Kennedy had surprised counsel for Massachusetts by mentioning the case

\footnotetext{
${ }^{68} 127 \mathrm{~S} \mathrm{Ct}$ at 1446.

${ }^{69}$ Id at 1454, quoting Georgia v Tennessee Copper Co., 206 US 230, 237 (1907).
} 
and describing it as "your best case" for establishing standing. ${ }^{70}$ Decided at a time when the Court itself served as an original forum for resolving environmental disputes between states, the Tennessee Copper decision upheld a state's right to an injunction to stop harm caused by pollution originating in another state.

Despite vigorous objections from Chief Justice Roberts joined by the other three dissenters, the holding on standing may prove to be the most significant aspect of the Court's decision. Building on previous warnings from Justice Kennedy that standing to enforce regulatory statutes should not require proof of common law injury, Justice Stevens's majority opinion firmly rejects the notion that litigants should only have access to court when the harm they assert is neither too small nor too large, but rather "just right"a kind of "Goldilocks" theory of standing. It also rejects the idea that standing is defeated if success enforcing a regulatory statute is unlikely to resolve more than a small portion of the problem the statute seeks to address. This represents a welcome appreciation of the realities of the modern administrative state and the purposes of precautionary regulation.

On closer analysis, Justice Kennedy's decision to join in full Justice Stevens's majority opinion on the issue of standing should not be that surprising. Justice Kennedy previously had been careful to indicate that his views on standing were not as extreme as Justice Scalia's. In Lujan $v$ Defenders of Wildlife Justice Kennedy authored an important concurring opinion, joined by Justice Souter, that significantly tempered the result because the two concurring Justices were part of a six-Justice majority. Justices Kennedy and Souter indicated that the purchase of a plane ticket or the announcement of a specific date on which members of the plaintiff group would visit sites affected by the challenged regulation would be sufficient to establish standing. Justice Kennedy also expressed greater receptivity to the plaintiff's "ecosystem nexus," "animal nexus," and "vocational nexus" theories of standing, ${ }^{71}$ which Justice Scalia had rejected with great disdain. He also clearly rejected the notion that standing should be limited by common law principles. "As Government programs and policies become more complex

\footnotetext{
${ }^{70}$ Transcript of Oral Argument, Massacbusetts v EPA, No 05-1120, *15 (argued Nov 29, 2006), online at http://www.supremecourtus.gov/oral_arguments/argument_transcripts/ 05-1120.pdf.

${ }^{71} 504$ US at 579 (Kennedy concurring in part and concurring in judgment).
} 
and far-reaching, we must be sensitive to the articulation of new rights of action that do not have clear analogs in our commonlaw tradition." 72 Justice Kennedy observed that "Congress has the power to define injuries and articulate chains of causation that will give rise to a case or controversy where none existed before . . .."73 In its discussion of standing, Justice Stevens's majority opinion in Massachusetts $v$ EPA quotes this language and emphasizes that Congress has authorized the very type of challenge to EPA action that the petitioners brought in the case.

The papers of the late Justice Harry A. Blackmun shed further light on Justice Kennedy's differences with Justice Scalia's efforts to restrict environmental standing. They reveal that Justice Kennedy stated that he was "not comfortable" in 1990 when voting with Justice Scalia at conference to restrict environmental standing in Lujan $v$ National Wildlife Federation. ${ }^{74}$ In Lujan $v$ Defenders of Wildlife, Justices Kennedy and Souter refused for months to join Justice Scalia's initial draft opinion because it sought to convert the prudential notion that courts should decline to hear generalized grievances into a constitutional one that would bar environmental plaintiffs from seeking redress for widely shared injuries. ${ }^{75}$ In a memo to Justice Scalia, Justice Souter wrote:

Despite ambiguous dicta in some of our cases, I doubt anyone would lack standing to sue on the basis of a concrete injury that everyone else has suffered; Congress might for instance, grant everyone standing to challenge government action that would rip open the ozone layer and expose all Americans to unhealthy doses of radiation. Yet the repeated references to a particularity requirement, which might be taken as conceptually independent of a concreteness requirement, draw that conclusion into doubt. ${ }^{76}$

After Justice Kennedy expressed agreement with Justice Souter and informed Justice Scalia that he would not join his majority opinion unless he deleted the references to "particularity," Justice Scalia

\footnotetext{
${ }^{72}$ Id at 580 .

${ }^{73} \mathrm{Id}$ at 580 .

${ }^{74} 497$ US 871 (1990).

${ }^{75}$ This is described in more detail in Robert V. Percival, Environmental Law in the Supreme Court: Highlights from the Blackmun Papers, 35 Envir L Rptr 10637, 10658-59 (2005).

${ }^{76}$ Letter from Justice David H. Souter to Justice Antonin Scalia (May 8, 1992), Harry A. Blackmun Papers, Manuscript Division, U.S. Library of Congress.
} 
made the requested changes. ${ }^{77}$ A law clerk later reported to Justice Blackmun that word had spread throughout the building that Justice Scalia was "irate at [Justice Kennedy] for submitting his concurrence and felt that it 'scuttled' his majority opinion." "78

Justice Scalia's campaign to restrict environmental standing suffered its worst setback eight years after Lujan, when all the Justices except for Scalia and Thomas joined Justice Ginsburg's majority opinion in Friends of the Earth $v$ Laidlaw Environmental Services. ${ }^{79}$ This decision rejected the notion that citizen plaintiffs must prove significant harm to the environment in order to establish standing to bring enforcement actions against polluters who violated their Clean Water Act permits. Traditional common law notions of standing initially would have barred the beneficiaries of regulation from having standing while providing regulated entities access to the courts. The Supreme Court halted this trend in Laidlaw, declaring that to insist that plaintiffs demonstrate "injury to the environment" would "raise the standing hurdle higher than the necessary showing for success on the merits in an action alleging noncompliance with [a Clean Water Act] permit." ${ }^{" 0}$ The Court instead endorsed standing for plaintiffs with reasonable concerns about the effects of environmental violations on the environment in areas where they live or recreate. ${ }^{81}$ The majority's broad view of environmental standing in Massachusetts $v$ EPA confirms the continued vitality of Laidlaw, though by a margin (5-4) substantially narrower than the 7-2 result in Laidlaw.

In its discussion of standing in Massachusetts $v$ EPA, Justice Stevens's majority opinion emphasizes the century-old precedent not cited in any of the briefs, but mentioned at oral argument by Justice Kennedy: Georgia $v$ Tennessee Copper Company. ${ }^{82}$ This case was a landmark in the development of the federal common law of interstate nuisance and the first case in which the U.S. Supreme Court issued an injunction to limit interstate pollution. In 1904 the state of Georgia invoked the Court's original jurisdiction over disputes between states to sue two companies that owned copper smelters

\footnotetext{
${ }^{77}$ Percival, Highlights from the Blackmun Papers at 10659 (cited in note 75).

${ }^{78} \mathrm{Id}$.

${ }^{79} 528$ US 167 (2000).

${ }^{80} \mathrm{Id}$ at 181 .

${ }^{81}$ Id at $181-89$.

${ }^{82} 206$ US 230 (1907).
} 
in the extreme southeast corner of Tennessee. Sulfur emissions from the smelters had destroyed vegetation over vast swaths of land extending into northern Georgia. Private nuisance suits against the companies operating the smelters-the Tennessee Copper Company and the Ducktown Sulphur, Copper \& Iron Company-had resulted in damages awards, but the Tennessee Supreme Court had refused to issue an injunction to limit the pollution because of the importance of the smelters to the local economy. ${ }^{83}$ The governor of Georgia had personally appealed to the governor of Tennessee to take action to stop the pollution, but the Tennessee governor responded that he had no authority to do so.

In October 1905 the U.S. Supreme Court agreed to hear Georgia's public nuisance claim, citing Missouri $v$ Illinois, ${ }^{84}$ where it had heard an original action involving interstate water pollution. In the Missouri case the Court had declared that "if the health and comfort of the inhabitants of a State are threatened, the State is the proper party to represent and defend them." ${ }^{" 55}$

Georgia litigated the case on the assumption that it would have to show damage to state property in order to be entitled to relief. Thus, it compiled evidence of erosion of public roads caused by the destruction of all vegetation in the vicinity of the smelters. More than two thousand affidavits ultimately were submitted to the record as well as the report of a commission appointed by the governor of Georgia to investigate the extent of harm caused by the smelter emissions. Georgia's conclusions were supported by testimony from three chemists, eight foresters, four entomologists, and a geologist. It submitted photographs to document the effects of the pollution, including the destruction of vegetation and attendant soil erosion. Affidavits were presented to document the destruction of crops, gardens, orchards, forests, and farms and injuries to roads and highways. More than fifteen hundred witnesses stated that the emissions had caused them some damage, including harm to their vocations and means of livelihood.

In the Court's decision, issued in May 1907, Justice Oliver Wendell Holmes deemed it unnecessary for Georgia to prove injury to state property. He noted:

\footnotetext{
${ }^{83}$ Madison v Ducktown Sulphur, Copper \& Iron Co., 83 SW 658, 659 (Tenn 1904).

${ }^{84} 180$ US 208 (1901).

${ }^{85}$ Id at 241 .
} 
The case has been argued largely as if it were one between two private parties; but it is not. The very elements that would be relied upon in a suit between fellow-citizens as a ground for equitable relief are wanting here. The State owns very little of the territory alleged to be affected, and the damage to it capable of estimate in money, possibly, at least, is small. . . . The alleged damage to the state as a private owner is merely a makeweight, and we may lay on one side the dispute as to whether the destruction of forests has led to the gullying of its roads. ${ }^{86}$

Because Georgia was suing "for an injury to it in its capacity of quasi-sovereign," Holmes declared that it "has an interest independent of and behind the titles of its citizens, in all the earth and air within its domain." ${ }^{\text {} 7}$ Thus, he concluded that the state's quasisovereign interest should give it "the last word as to whether its mountains shall be stripped of their forests and its inhabitants shall breathe pure air." 88 Because the Court found that the evidence clearly established that sulfur emissions from the smelters caused significant damage in Georgia, it declared that the state was entitled to an injunction to limit the emissions. Relying on this precedent a century later, the Massachusetts $v$ EPA Court concluded that the Commonwealth of Massachusetts "is entitled to special solicitude in our standing analysis." ${ }^{89}$

In his dissent, Chief Justice Roberts argues that the majority has created a new relaxed standard of standing for cases brought by states. He maintains that the discussion of quasi-sovereign state interests in Tennessee Copper was not relevant to the question of standing, but rather to a state's greater entitlement to equitable relief when it sues in the capacity of parens patriae. To be sure, Tennessee Copper predated by several decades the appearance of standing as a distinct analytical concept in the Court's jurisprudence. ${ }^{90}$ But the logic behind the Court's willingness to entertain an action by a state to protect its citizens from environmental harm caused by sources outside its jurisdiction-that the state's entry into the union ceded to the federal government (as represented by the Supreme Court) the state's ability to defend its sovereign interests

\footnotetext{
${ }^{86}$ Georgia v Tennessee Copper Co., 206 US at 237.

${ }^{87} \mathrm{Id}$.

${ }^{88} \mathrm{Id}$.

${ }^{89} 127 \mathrm{~S}$ Ct at $1454-55$.

${ }^{90}$ Stark v Wickard, 321 US 288, 310 (1944).
} 
against pollution originating outside its boundaries-is entirely unaffected by the development of standing doctrines.

Moreover, Justice Stevens's majority opinion then goes on to explain in completely conventional terms why Massachusetts meets every element of traditional standing doctrine: injury, causation, and redressability. He states that the standing affidavits submitted by the Commonwealth "have satisfied the most demanding standards of the adversarial process." 91 Thus, while the majority's discussion of standing plausibly can be interpreted as relying on a special rule of standing for states, it is better understood as holding that the state would have standing without the need for any special rule, contrary to the assertions of the Chief Justice. Contrary to the Chief Justice's surmise, the failure of any litigant to cite Tennessee Copper is probably more of a commentary on the litigants' neglect of legal history than on the decision's precedential value.

This is not meant to suggest that it necessarily would be a bad idea to establish special standing rules for cases involving challenges to decisions by administrative agencies. The traditional private law model of litigation involving plaintiffs alleging harm caused by the actions of a specific defendant seems ill-suited to litigation challenging decisions by administrative agencies. Agencies were created to establish precautionary regulations preventing harm before it occurs. Actions to require agency fidelity to laws authorizing precautionary regulation should not require plaintiffs to demonstrate the kind of injury that would give rise to redress under the common law. The Court already has recognized this, at least implicitly, by establishing special standing rules for cases involving allegation of procedural injury. A wholesale rethinking of standing doctrine applicable to challenges to agency action would be a most welcome development.

Perhaps the most significant portion of the majority opinion is its discussion of the conventional elements of standing. Gone is the "code-pleading formalism" of Justice Scalia's Lujan opinion" that sought to use standing doctrine expressly to disadvantage environmental interests. The Court's approach instead is reminiscent of Sierra Club v Morton where it described the purpose of standing as "a rough attempt to put the decision as to whether review will be

\footnotetext{
${ }^{91} 127 \mathrm{~S} \mathrm{Ct}$ at 1455.

${ }^{92}$ Lujan v Defenders of Wildlife, 504 US 555, 593 (1992) (Blackmun dissenting).
} 
sought in the hands of those who have a direct stake in the outcome" that will neither "insulate executive action from judicial review" nor "prevent any public interests from being protected through the judicial process." ${ }^{93}$ Addressing the injury prong of standing doctrine, the majority forcefully rejects the notion advocated by Justice Scalia in Lujan that injuries that are widely shared cannot give rise to standing. ${ }^{94}$ The Court concludes that the harms caused by climate change-sea level rise destroying coastal property, irreversible harm to natural ecosystems, reduction of water storage in snowpack, and an increase in the ferocity of storms and the spread of diseasecan give rise to standing even though they will affect vast areas and large populations. ${ }^{95}$ Thus, the Court expressly rejects the "Goldilocks" approach to standing - the notion that the injury alleged by plaintiffs has to be neither too small nor too large, but "just right."

Equally important is the Court's treatment of the causation and redressability prongs of standing doctrine. The Court rejects the notion that because auto emissions are only a small portion of total global greenhouse gas emissions they cannot give rise to standing. Justice Stevens notes that regulatory agencies "do not generally resolve massive problems in one fell regulatory swoop." ${ }^{96}$ He deems "erroneous" the "assumption that a small incremental step, because it is incremental, can never be attacked in a federal judicial forum." This is enormously important because a contrary rule "would doom most challenges to regulatory action." ${ }^{98}$ Likewise the plaintiffs need not demonstrate that success in court in itself will solve the climate change problem, only that it will help slow or reduce it. Even if developing countries increase their emissions of greenhouse gases, a reduction in domestic emissions will help slow the pace of climate change, which is sufficient for meeting the redressability requirement. $^{99}$

The Court summarizes why it finds plaintiffs to have standing in the following manner:

\footnotetext{
${ }^{93}$ Sierra Club v Morton, 405 US 727, 740 (1972).

${ }^{94} 127 \mathrm{~S}$ Ct at 1456.

${ }^{95} \mathrm{Id}$ at $1456-57$.

${ }^{96} \mathrm{Id}$ at 1457.

${ }^{97} \mathrm{Id}$.

${ }^{98} \mathrm{Id}$.

${ }^{99}$ Id at 1458 .
} 
[T] he rise in sea levels associated with global warming has already harmed and will continue to harm Massachusetts. The risk of catastrophic harm, though remote, is nevertheless real. That risk would be reduced to some extent if petitioners received the relief they seek. We therefore hold that petitioners have standing to challenge the EPA's denial of their rulemaking petition. ${ }^{100}$

In a strident dissent, Chief Justice Roberts maintains that even if global warming is a "crisis" and "the most pressing environmental problem of our time," the Court should not hear this case because it is a problem best addressed by Congress and the President. ${ }^{101}$ Dismissing the forty-three unchallenged declarations submitted by petitioners about the adverse impact of climate change as "pure conjecture," he argues that global warming is too widespread, occurring over too long a time span, and affected by too many other complexities for the contribution from emissions of U.S. motor vehicles to give rise to standing. Even though this source represents 6 percent of global carbon dioxide emissions and 4 percent of global greenhouse gas emissions, the Chief Justice deems it to be playing only a "bit part" in the climate change problem. He does not state precisely how large, how concentrated, how fast, or how free of other complexities a source category's contribution to the problem would have to be to give rise to standing.

The Chief Justice's dissent illustrates the inappropriateness of applying private law models of adversary litigation when determining who should be able to seek judicial review of decisions by administrative agencies. Unlike the traditional model of private law litigation where one party seeks redress for harm caused by another, public law litigation seeks to require agencies to conform to law when exercising their regulatory authorities to prevent diffuse harm to the general public. If plaintiffs must demonstrate the same level of individualized proof of causal injury that could give rise to liability at common law before they can access courts to compel agencies to obey the law, the law's precautionary purposes will be severely undermined. Moreover, courts reviewing public law challenges to agency action are not well equipped to make the kind of factual determinations of causal injury that the private law model requires.

Chief Justice Roberts suggests in his dissent that no matter how

\footnotetext{
${ }^{100} \mathrm{Id}$.

${ }^{101}$ Id at 1463 (Roberts dissenting).
} 
serious an environmental problem may be, no one should be able to enforce an agency's legal obligation to respond to it unless they can demonstrate something akin to the kind of causal injury that would be redressable in a common law action. This ignores the fact that the very laws Congress authorized citizens to enforce were adopted in reaction to the inadequacies of the common law for preventing chronic and diffuse environmental harm. Reimporting stringent common law causation requirements into standing analysis would make it impossible for anyone to enforce these laws, frustrating achievement of the congressional purpose.

The Chief Justice's dissent echoes the arguments made by dissenters in a crucial, early D.C. Circuit decision upholding EPA's first regulations limiting the amount of lead additives in gasoline. ${ }^{102}$ Standing was not at issue in that case because it involved a challenge made by the lead industry, which maintained that the regulations should be invalidated because EPA could not prove specific harm to public health caused by lead emissions from gasoline. EPA argued that the harmful effects of lead were well known, that gasoline lead additives significantly contributed to levels of lead in the ambient air, and that this added significantly to the total body burden of lead, harming public health. However, a panel of the court initially invalidated the regulations, finding by a $2-1$ vote that the case against gasoline additives was "speculative and inconclusive [ ] at best" because the agency could not prove that specific instances of harm to public health had been caused by gasoline lead additives. ${ }^{103}$

The D.C. Circuit then reviewed the case en banc, parsing a record that ran for more than ten thousand pages. It ultimately reversed the panel by a 5-4 vote, upholding the EPA regulations. In his dissent, Judge Wilkey argued that EPA had not adequately demonstrated a causal connection between lead emissions and harm to public health. "[O]nly if the Administrator can say that an identifiable measurable increment of lead in the human body is derived from auto fuel additives and that this measurable increment of lead itself (taking into consideration all other sources of lead) causes a significant health hazard, can the Administrator claim that controlling or prohibiting lead would reduce significantly such health

\footnotetext{
${ }^{102}$ Ethyl Corp. $v$ EPA, 541 F2d 1 (DC Cir 1976) (en banc).

${ }^{103}$ Ethyl Corp. v EPA, 5 Envir L Rptr 20096, 20097 (DC Cir, Jan 28, 1975).
} 
hazard." ${ }^{104}$ Writing for the majority, Judge J. Skelly Wright rejected this approach:

Where a statute is precautionary in nature, the evidence difficult to come by, uncertain, or conflicting because it is on the frontiers of scientific knowledge, the regulations designed to protect the public health, and the decision that of an expert administrator, we will not demand rigorous step-by-step proof of cause and effect. Such proof may be impossible to obtain if the precautionary purpose of the statute is to be served..$^{105}$

The court held that EPA's reasoning was sound and adequately supported by the evidence, rejecting the notion that the agency should be required to produce a definitive study quantifying the harm from gasoline lead additives.

Writing for the dissenters, Judge Wilkey noted that many other sources of lead exposure existed (e.g., diet, drinking water, peeling lead-based paint) and that EPA could not quantify the precise increment contributed by emissions from gasoline lead additives. $\mathrm{He}$ argued that only convincing proof of actual harm would suffice and he decried the "amazing lengths" the majority will go "to produce a decision for some uncertain, ill-defined, supposed environmental benefit." 106 Judge Wright responded that it made no sense to employ "tunnel-like reasoning"107 that would foreclose regulation of gasoline lead additives simply because other sources of lead exposure contributed to the lead poisoning problem, particularly when "lead automobile emissions were, far and away, the most readily reduced significant source of environmental lead." ${ }^{108}$

Chief Justice Roberts's arguments that there is insufficient proof of harm from climate change to establish standing mirror the arguments of the Ethyl dissenters. In addition to deeming the harm to be too uncertain and insufficiently documented, the Chief Justice argues that because other sources contribute to the harm, standing

\footnotetext{
${ }^{104} 541$ F2d 1, 95 (Wilkey dissenting).

${ }^{105} \mathrm{Id}$ at 28 (Wright majority opinion) (footnote omitted). In a footnote to his majority opinion in Massachusetts v EPA Justice Stevens quotes from the Ethyl majority's statement that the Clean Air Act and "common sense . . . demand regulatory action to prevent harm, even if the regulator is less than certain that harm is otherwise inevitable." $127 \mathrm{~S}$ Ct 1438,1447 n 7.

${ }^{106} 541 \mathrm{~F} 2 \mathrm{~d}$ at 104 (Wilkey dissenting).

${ }^{107} \mathrm{Id}$ at 30 (Wright majority opinion).

${ }^{108} 541$ F2d 1, 31 (Wright majority opinion).
} 
is foreclosed. He opines that Massachusetts fails to meet the redressability prong of standing doctrine because future increases in greenhouse gas emissions from China and India may wipe out any benefit from controlling U.S. vehicle emissions. Yet, as Justice Stevens notes, any reductions in greenhouse gas emissions achieved by EPA regulation will contribute to some reduction in the harmful effects of climate change, an argument the Chief Justice characterizes as: "Every little bit helps, so Massachusetts can sue over any little bit." 109 Justice Stevens responds that accepting the premise "that a small incremental step, because it is incremental, can never be attacked in a federal judicial forum . . . would doom most challenges to regulatory action." ${ }^{110}$ The history of EPA's regulation of gasoline lead additives amply demonstrates this. The regulation upheld in Ethyl was a crucial initial step in the total phaseout of gasoline lead additives, a measure now generally considered to be among the most beneficial EPA ever has adopted and one now widely emulated throughout the world.

To be sure, Ethyl was not a case about standing, but as the Court indicated in Laidlaw the factual showing necessary to establish standing should not be more onerous than that needed to establish success on the merits. ${ }^{111}$ Yet Chief Justice Roberts's dissent in Massachusetts $v E P A$ seems to advocate a return to such an approach. Because the Chief Justice's opinion is joined by the three other dissenters, it confirms that the Court is now even more sharply divided in its approach to standing than it was in Laidlaw, where only Justices Scalia and Thomas embraced extraordinarily restrictive requirements for environmental plaintiffs.

The Chief Justice concludes by arguing that the majority has "made standing seem a lawyer's game" by adopting "utterly manipulable" standards reminiscent of the Court's approach in $S C R A P^{112}$ One can fairly question whose approach to standingthe majority's or the dissent's - is more prone to manipulation and more likely to be used systematically to bar certain types of plaintiffs from access to the courts. The majority's approach to standing clearly is more compatible with lawsuits by the beneficiaries of environmental regulation who are more numerous and more widely

\footnotetext{
${ }^{109} 127 \mathrm{~S} \mathrm{Ct}$ at 1470 (Roberts dissenting).

${ }^{110} \mathrm{Id}$ at 1457 (Stevens majority opinion).

${ }^{111}$ Friends of the Earth v Laidlaw Environmental Services, Inc., 528 US 167, 181 (2000).

${ }^{112} 127 \mathrm{~S} \mathrm{Ct}$ at 1471 (Roberts dissenting).
} 
dispersed than business interests regulated under the environmental statutes.

\section{B. SCOPE OF REGULATORY AUTHORITY UNDER THE CLEAN AIR ACT}

As illustrated by its decision in the Rapanos case, the Roberts Court has been sharply divided on issues involving the scope of federal regulatory authority under the environmental laws. Some observers of the Court believed that this split would not reemerge in Massachusetts $v$ EPA because-assuming the Court reached the issue, instead of deciding the case on grounds of standing or of the EPA's discretion not to decide-the language of the Clean Air Act was so sweeping that the question of the EPA's authority to regulate emissions of greenhouse gases that contribute to climate change was not a close one. However, the Court ultimately split 5-4 on the question of EPA's authority.

Section 202(a)(1) of the Clean Air Act empowers EPA to prescribe by regulation "standards applicable to the emission of any air pollutant from any class or classes of new motor vehicles or new motor vehicle engines, which in [the EPA Administrator's] judgment cause, or contribute to, air pollution which may reasonably be anticipated to endanger public health or welfare."113 In 1998 EPA's general counsel issued a legal opinion finding that carbon dioxide, a greenhouse gas, could be regulated under the Clean Air Act, a position endorsed by his successor in 1999. When EPA denied the petition to regulate greenhouse gas emissions from motor vehicles, its new general counsel revoked the prior legal opinion and replaced it with his own. The new opinion concluded that carbon dioxide is not an "air pollutant" regulable under the Act and thus EPA did not have the authority to grant the relief requested in the petition.

To justify this conclusion, EPA relied heavily on the Court's decision in FDA $v$ Brown \& Williamson Tobacco Corp. ${ }^{114}$ In that case a 5-4 majority reversed efforts by the U.S. Food and Drug Administration (FDA) to regulate tobacco products under the federal Food, Drug \& Cosmetic Act (FDCA). While the FDA had long believed that it did not have the authority to regulate tobacco products under the FDCA, it changed its mind after concluding

\footnotetext{
${ }^{113} 42$ USC $\$ 7521(\mathrm{a})(1)(2000)$.

${ }^{114} 529$ US 120 (2000).
} 
that tobacco products were used primarily to deliver nicotine to smokers, bringing them within the definition of "drug delivery devices" subject to regulation under the FDCA.

Rather than deferring to the agency's interpretation of its regulatory authorities pursuant to Chevron, the majority in Brown \& Williamson concluded that Congress clearly did not intend to give FDA the authority to regulate tobacco products because the agency might be required to ban them entirely to achieve the goals of the Act. Writing for the majority, Justice O'Connor described the thousands of premature deaths from smoking-related diseases to be "one of the most troubling public health problems facing our Nation today." 115 But she concluded that no matter how serious the problem the agency seeks to address, it could not go beyond the bounds of the authority given it by Congress. ${ }^{116}$

In similar fashion, EPA argued in Massachusetts $v$ EPA that because Congress was aware of the importance of the problem of climate change, but had not expressly given the agency a directive to regulate emissions that cause it, the agency lacked the authority to do so under the Clean Air Act. Thus, it concluded that greenhouse gases could not be considered to be "air pollutants" subject to regulation under the Act.

Despite the agency's Brown \& Williamson argument, EPA's refusal to regulate greenhouse gas emissions bore all the earmarks of a politically dictated decision for which the agency had to manufacture a supporting legal rationale. The clear text of the Act seems to contradict the agency's position. The Clean Air Act broadly defines "air pollution" to include "any air pollution agent or combination of such agents, including any physical, chemical, biological, radioactive . . substance or matter which is emitted into or otherwise enters the ambient air." 117 On its face, it is difficult to see how greenhouse gases could fail to be covered by such a broad definition. EPA has a legal obligation under the Clean Air Act to regulate air pollutants from motor vehicles that "cause, or contribute to, air pollution which may reasonably be anticipated to endanger public health or welfare ..."118 and "welfare" is

\footnotetext{
${ }^{115} \mathrm{Id}$ at 125 .

${ }^{116} \mathrm{Id}$.

11742 USC $\$ 7602(\mathrm{~g})(2000)$.

${ }^{118} 42$ USC $\$ 7521(\mathrm{a})(1)(2000)$.
} 
broadly defined to include "effects on . . . weather . . . and climate."119

In his majority opinion, Justice Stevens concluded that the statutory text of the Clean Air Act unambiguously includes carbon dioxide and other greenhouse gases within the definition of "air pollutant": "On its face, the definition embraces all airborne compounds of whatever stripe, and underscores that intent through the repeated use of the word 'any." ${ }^{120} \mathrm{He}$ rejected any notion that Congress had implicitly directed EPA not to regulate greenhouse gases as not remotely plausible and found no conflict between congressional funding for climate change research and any preexisting mandate to regulate harmful air pollutants.

Perhaps the most significant portion of the Court's discussion of statutory interpretation is its treatment of Brown \& Williamson. Justice Stevens distinguished the decision on several grounds. First he notes that, unlike tobacco products regulated as "drugs," EPA would not be required to ban all emissions of greenhouse gases, but rather only to regulate them. (To be sure, FDA had disclaimed any intent to ban tobacco in Brown \& Williamson, but the Court majority nonetheless expressed the view that the Food, Drug \& Cosmetic Act would require such radical action.) Second, unlike the FDA, EPA had not long disclaimed authority to regulate greenhouse gas emissions and Congress had not enacted legislation confirming the lack of such authority. Finally, the Court rejected the notion that regulation of greenhouse gas emissions from motor vehicles necessarily would conflict with the Department of Transportation's (DOT's) duty to set fuel efficiency standards, an argument made by auto manufacturers seeking to preempt state controls on emissions from their products. The Court concluded that the fact "that DOT sets mileage standards in no way licenses EPA to shirk its environmental responsibilities. . . The two obligations may overlap, but there is no reason to think the two agencies cannot both administer their obligations and yet avoid inconsistency." 121

The Court majority concluded by noting that Congress designed the Clean Air Act to provide comprehensive protection

\footnotetext{
11942 USC $\$ 7602(\mathrm{~h})(2000)$.

${ }^{120} 127 \mathrm{~S} \mathrm{Ct}$ at 1460 (Stevens majority).

${ }^{121} \mathrm{Id}$ at 1462 .
} 
against air pollution and to be capable of responding to changed circumstances and new scientific understandings. "While the Congresses that drafted $\$ 202(a)(1)$ might not have appreciated the possibility that burning fossil fuels could lead to global warming, they did understand that without regulatory flexibility, changing circumstances and scientific developments would soon render the Clean Air Act obsolete." 122 This is reflected in the broad language used by Congress in "an intentional effort to confer the flexibility necessary to forestall" the Act from becoming obsolete. The Court concluded that "[b]ecause greenhouse gases fit well within the Clean Air Act's capacious definition of 'air pollutant' . . . EPA has the statutory authority to regulate the emission of such gases from new motor vehicles." 123

In dissent Justice Scalia argues that greenhouse gases are not "agent[s] of air pollution" 124 because substances that pollute the air do so primarily only at ground level or near the surface of the earth. According to Scalia, EPA's conception of what constitutes air pollution properly focuses on impurities in the ambient air at ground level or near the surface of the earth and not on substances in the upper atmosphere like greenhouse gases. He derives this conclusion-which seems dubious, in view of the expansive language of the statute-by focusing on dictionary definitions of the words "pollute" ("[t]o make or render impure or unclean") and "air" that focus more on air at ground level. ${ }^{125}$

Four of the Justices in the majority in Massachusetts $v$ EPAJustices Breyer, Stevens, Souter, and Ginsburg-were the four dissenters in Brown \& Williamson. Justice Kennedy is the lone defector from the majority in Brown \& Williamson. The two newest members of the Court-Chief Justice Roberts and Justice Alito-join Justices Scalia and Thomas, who were in the majority in Brown \& Williamson, in adopting its approach to statutory interpretation. This may not herald a long-term shift away from Brown o Williamson because it is unclear how durable Justice Kennedy's defection will be. Two months after Massachusetts $v$ EPA was decided, Justice Kennedy rejoined the four dissenters from that case to form a five-Justice majority in National Association of Homebuilders

\footnotetext{
${ }^{122}$ Id.

${ }^{123} \mathrm{Id}$.

${ }^{124} \mathrm{Id}$ at 1476 (Scalia dissenting) (alteration in original).

${ }^{125} \mathrm{Id}$ at 1477 .
} 
$v$ Defenders of Wildlife. ${ }^{126}$ In that case the Court refused to read important requirements of the Endangered Species Act (ESA) as compatible with the Clean Water Act (CWA). The Court held that the crucial consultation and no-jeopardy provisions of Section 7 of the ESA are not applicable when EPA delegates administration of the CWA's national permit program to states because those provisions apply only when a federal agency is engaged in discretionary action. This stands in sharp contrast with the Massachusetts $v$ EPA majority's conclusion that the Clean Air Act should be read flexibly to avoid conflict with the Energy Policy and Conservation Act.

\section{EXERCISE OF AGENCY DISCRETION}

To justify its denial of the petition to regulate greenhouse gas emissions from motor vehicles, EPA concluded that even if it had the authority to regulate such emissions, it would decline to do so. But the majority in Massachusetts $v$ EPA rejected this conclusion on the ground that it was founded on "reasoning divorced from the statutory text." 127 The Court conceded that EPA "has significant latitude as to the manner, timing, content, and coordination of its regulations with those of other agencies." 128 But it stated that this was "not a roving license to ignore the statutory text," but rather "a direction to exercise discretion within defined statutory limits." ${ }^{129}$ Thus, it held that:

Under the clear terms of the Clean Air Act, EPA can avoid taking further action only if it determines that greenhouse gases do not contribute to climate change or if it provides some reasonable explanation as to why it cannot or will not exercise its discretion to determine whether they do. ${ }^{130}$

Because climate change is a global problem that will be solved only if addressed globally, EPA had sought to defend its refusal to regulate greenhouse gas emissions on the ground that it might interfere with the President's ability to negotiate a global solution.

\footnotetext{
${ }^{126} 127$ S Ct 2518 (2007).

${ }^{127} 127 \mathrm{~S} \mathrm{Ct}$ at 1462 .

${ }^{128} \mathrm{Id}$.

${ }^{129} \mathrm{Id}$.

${ }^{130} \mathrm{Id}$.
} 
The Court brushed aside these concerns. While noting that it had "neither the expertise nor the authority to evaluate these policy judgments," it concluded that they did not "amount to a reasoned justification for declining to form a scientific judgment" about the impact of greenhouse gas emissions from motor vehicles on climate change. ${ }^{131}$

The Court expressly rejected the notion that the President's foreign policy powers could trump domestic environmental mandates. It recognized that "the President has broad authority in foreign affairs," but it declared that such "authority does not extend to the refusal to execute domestic laws." 132 An amicus brief filed on behalf of former Secretary of State Madeleine Albright argued that there is no tension between domestic regulation of greenhouse gas emissions and the ability of the United States to conduct foreign policy on climate change, particularly since the U.S. policy has been to encourage other nations to take voluntary action to reduce such emissions. ${ }^{133}$ The brief also warned of the danger of allowing foreign policy concerns to trump domestic legal requirements.

Finally, the Court rejected the notion that uncertainty surrounding various aspects of climate change justified EPA's refusal to act. "If the scientific uncertainty is so profound that it precludes EPA from making a reasoned judgment as to whether greenhouse gases contribute to global warming, EPA must say so." ${ }^{134}$ The Court declared that the agency's expressed policy preference not to regulate greenhouse gas emissions "because of some residual uncertainty" is "irrelevant" to the statutory question of "whether sufficient information exists to make an endangerment finding." 135 The Court thus found that EPA had acted arbitrarily and capriciously because it had not offered a "reasoned explanation for its refusal to decide whether greenhouse gases cause or contribute to climate change." 136

In his dissent, Justice Scalia argued that EPA had no obligation

\footnotetext{
${ }^{131} \mathrm{Id}$ at 1463 .

${ }^{132} \mathrm{Id}$

${ }^{133}$ Brief for Amicus Curiae Madeleine K. Albright in Support of Petitioners, Massachusetts $v$ EPA, No 05-1120 (filed Aug 31, 2006) (available on Westlaw at 2006 WL 2570988).

${ }^{134} 127 \mathrm{~S}$ Ct at 1463.

${ }^{135} \mathrm{Id}$.

${ }^{136} \mathrm{Id}$.
} 
to decide whether greenhouse gas emissions contribute to climate change because it had sufficient reasons to defer making such a judgment. Justice Scalia stated that he is "willing to assume" arguendo "that the Administrator's discretion in this regard is not entirely unbounded-that if he has no reasonable basis for deferring judgment he must grasp the nettle at once." ${ }^{137}$ But he concluded that the reasons offered by EPA were "perfectly valid reasons" for deferring judgment. Justice Scalia argued that the Clean Air Act "says nothing at all about the reasons for which the Administrator may defer making a judgment . . . ."138 Thus, he concluded that there is no warrant for the majority's claim that the reasons proffered by the Administrator are divorced from the statutory text. In fact he maintained that EPA has indeed "said precisely" that scientific uncertainty is so profound that it precludes the agency from making a reasoned judgment whether greenhouse gases contribute to global warming. ${ }^{139}$ Justice Scalia and the other three dissenters thus are willing to wrap EPA in the mantle of global warming skeptics to defend the agency's refusal to act. The fact that a view so divorced from the scientific mainstream would command deference from four Justices of the U.S. Supreme Court is disheartening.

There is nothing truly exceptional about the Court's decision from the standpoint of administrative law. The Court did confirm that agency denials of rulemaking petitions are subject to judicial review, distinguishing them from refusals to initiate enforcement actions, ${ }^{140}$ but this was consistent with the prior conclusions of the courts of appeals. While it may be true that the U.S. Supreme Court itself had never before reversed an agency's denial of a rulemaking petition, this may be a product of the fact that most such petitions languish unanswered by agencies. The Administrative Procedure Act provides for judicial review of "agency action," which is defined to include "the whole or a part of an agency rule . . . or denial thereof, or failure to act." ${ }^{141}$ As the Court notes, ${ }^{142}$ the Clean Air Act's judicial review provisions provide for review

\footnotetext{
${ }^{137}$ Id at 1472 (Scalia dissenting).

${ }^{138} \mathrm{Id}$ at 1473 (emphasis in original).

${ }^{139} \mathrm{Id}$ at 1474 .

${ }^{140} \mathrm{Id}$ at 1459 (Stevens majority opinion).

${ }^{141} 5$ USC $\$ 702$ (2000); 5 USC $\$ 551(13)$ (2000).

${ }^{142} 127 \mathrm{~S} \mathrm{Ct}$ at $1451 \mathrm{n} 16$.
} 
of decisions promulgating standards under $\$ 202$ of the Act and of "final action" taken under the Act, which would seem to include denial of the petition at issue in the case. There was no controversy over the reviewability of EPA's action and the Court's decision simply confirms what already was widely understood. In this sense it is akin to the Court's State Farm decision where the Court itself confirmed for the first time that arbitrary and capricious review was not toothless even as applied to an agency's decision to rescind previously issued regulations. ${ }^{143}$ Thus, the Massachusetts $v$ EPA decision breaks no new ground from the standpoint of judicial review of an agency's refusal to act.

However, the majority's willingness to push EPA toward grasping the regulatory "nettle" does stand in sharp contrast to the approach the judiciary embraced during the 1980s when environmentalists sought to force the agency to take action to control the nation's acid rain problem. Even though the Clean Air Act had provisions giving EPA authority to force upwind sources of pollution to reduce emissions to prevent harm to downwind states, EPA refused to exercise such authority. Despite mounting evidence of the damage caused by acid rain, in case after case brought by environmental interests, the courts refused to force EPA to act. In one case, then Circuit Judge Ruth Bader Ginsburg was remarkably candid in explaining why the judiciary was unwilling to require EPA to act:

As counsel for the EPA acknowledged at oral argument, the EPA has taken $n o$ action against sources of interstate air pollution under either $\$ 126(\mathrm{~b})$ or $\$ 110(\mathrm{a})(2)(\mathrm{E})$ in the decadeplus since those provisions were enacted. Congress, when it is so minded, is fully capable of instructing the EPA to address particular matters promptly. . . . Congress did not supply such direction in this instance; instead, it allowed and has left unchecked the EPA's current approach to interstate air pollution. The judiciary, therefore, is not the proper place in which to urge alteration of the Agency's course. ${ }^{144}$

In Massachusetts $v$ EPA it is the Supreme Court, and not the D.C. Circuit, that is requiring the agency to reconsider its refusal to decide whether to regulate. Perhaps because climate change is

\footnotetext{
${ }^{143}$ Motor Vehicle Mfrs. Ass'n v State Farm Mutual Auto. Insur. Co., 463 US 29 (1983).

${ }^{144}$ New York v EPA, 852 F2d 574, 581 (DC Cir 1988) (R. Ginsburg, concurring).
} 
now considered a global environmental crisis far more serious than the problem of acid rain, the Court is unwilling to tolerate continued executive inaction. It also rejects what in this age of globalization could become a nearly universally applicable excuse for agency inaction-that domestic regulation might interfere with the President's ability to negotiate a global approach to a problem.

Professor Ronald Cass opines that "the Justices stretch, twist, and torture administrative law doctrines to avoid the inconvenient truth that this is not a matter in which judges have any real role to play." 145 But in fact the Court is resuming precisely the role it played in the early twentieth century in responding to states' concerns about environmental problems originating outside their borders. When activities causing significant, foreseeable environmental harm had not been controlled by other government entities, the judiciary for centuries was the vehicle for providing redress. Now this role has been largely delegated to administrative agencies by the enactment of comprehensive regulatory programs to protect the environment. In Massachusetts $v E P A$ the Court acts to require EPA to reconsider using these authorities to address a critical global problem, a far more modest step than those the Court took in the days when it wrote its own pollution control injunctions.

\section{The Implications of Massachusetts v EPA}

The states' effort to force EPA to regulate greenhouse gas emissions from motor vehicles is only one of many legal initiatives that respond to the climate change problem. ${ }^{146}$ Yet the Court's decision in Massachusetts $v E P A$ is likely to have effects that extend far beyond the issues addressed in the case. First, the Court's decision appears to confirm that standing doctrine is still comfortably in the mold of the Laidlaw and Sierra Club $v$ Morton model that does not employ it as a vehicle to disadvantage environmental interests. While Chief Justice Roberts's dissent attempts to confine the Court's holding on standing to a special rule only applicable

\footnotetext{
${ }^{145}$ Ronald A. Cass, Massachusetts v. EPA: The Inconvenient Truth About Precedent, Va L Rev In Brief 75 (May 21, 2007), online at http://www.virginialawreview.org/inbrief/2007/ 05/21/cass.pdf.

${ }^{146}$ See, e.g., Justin R. Pidot, Georgetown Environmental Law \& Policy Institute, Global Warming in the Courts: An Overview of Current Litigation and Common Legal Issues (Georgetown Univ, 2006), online at http://www.law.georgetown.edu/gelpi/current_research/documents/GWL_Report.pdf.
} 
to states, the Court's discussion of each element of traditional standing doctrine suggests that the decision is not so confined. Yet because both the Chief Justice and Justice Alito embraced the restrictive vision of standing Justice Scalia has long championed, Massachusetts $v$ EPA clarifies that the Court is now more closely divided on this issue than it was in 2000 when Laidlaw was decided.

It is highly important that the Court majority expressly rejected the notion that standing cannot be premised on harm that is widely shared, burying the "Goldilocks" approach to standing. The Court also clearly rejected the claim that standing is unavailable on redressability grounds unless the relief sought by litigants is likely to solve most of a problem. Following the Court's decision, a federal district court rejected a challenge to state regulations to control greenhouse gas emissions and noted:

The fact that global warming will not be solved by changes in any one industry or by regulation of any one source of emissions in no way undercuts the vital nature of the problem or the validity of partial responses; rather, it points to the necessity of responses, however incomplete when viewed individually, on any number of fronts. ("Agencies, like legislatures, do not generally resolve massive problems in one fell regulatory swoop. They instead whittle away at them over time."). ${ }^{147}$

Second, the Court's decision that the Clean Air Act gives EPA the authority to regulate emissions of greenhouse gases raises the question whether the Act now preempts common law nuisance litigation premised on climate change. As noted above, more than a quarter century ago the Supreme Court held that the federal Clean Water Act preempted the federal common law of nuisance for interstate water pollution. ${ }^{148}$ In Connecticut $v$ American Electric Power Company ${ }^{149}$ eight states and the City of New York are pursuing a federal and state common law nuisance action against six of the largest electric utilities in the United States, which together account for 10 percent of U.S. emissions of carbon dioxide. The plaintiffs in this case are asking the court to order the defendants

\footnotetext{
${ }^{147}$ Green Mountain Chrysler Plymouth Dodge Jeep v Crombie, 508 F Supp 2d 295, 320 (D Vt 2007), quoting Massachusetts v EPA, $127 \mathrm{~S} \mathrm{Ct}$ at 1457.

${ }^{148}$ City of Milwaukee v Illinois, 451 US 304 (1981).

${ }^{149} 406$ F Supp 2d 265 (SDNY 2005), on appeal to the U.S. Court of Appeals for the Second Circuit.
} 
to make modest annual reductions in their emissions of greenhouse gases. So long as EPA took the position that it had no authority under the Clean Air Act to regulate emissions of greenhouse gases, no one could credibly argue that the Act preempted the federal common law of nuisance. Now that the U.S. Supreme Court has ruled to the contrary, it is possible the Clean Air Act will be found to have such preemptive effect.

Two years ago a federal district judge in New York dismissed Connecticut $v$ American Electric Power on political question grounds and the case is now before the U.S. Court of Appeals for the Second Circuit on appeal. Shortly after Massachusetts $v$ EPA was decided, the Second Circuit asked the parties in this appeal to express their views on the impact of the decision on the appeal. Plaintiffs responded by arguing that although the Court clarified that the Clean Air Act gives EPA authority to regulate emissions of greenhouse gases, the Act cannot preempt a federal common law nuisance action until EPA actually issues such regulations. Defendants maintained that the mere fact that the Act provides EPA with authority to address climate change gives it preemptive effect even if EPA has chosen not to exercise such authority.

Plaintiffs would seem to have the better of the argument. The Court's decision in City of Milwaukee $v$ Illinois, which held the Clean Water Act preempts the federal common law of nuisance, was premised on the comprehensive nature of the regulatory scheme enacted by Congress. The Clean Water Act itself prohibits all discharges of pollutants to surface waters unless they are authorized by a permit issued pursuant to the Act. Following the enactment of the 1990 Clean Air Act Amendments, the Clean Air Act now provides for a national permit program, but it does not include any direct regulation of emissions of greenhouse gases. Thus, until EPA acts either to establish such regulations or expressly to preempt other control of them, the federal common law in this area would not appear to be preempted. ${ }^{150}$ However, the political question ground for upholding dismissal of the action is still available. In September 2007 a federal district court in San Francisco dismissed a climate change nuisance suit brought by the

\footnotetext{
${ }^{150}$ But see Shi-Ling Hsu, A Realistic Evaluation of Climate Change Litigation Through the Lens of a Hypothetical Lawsuit, $78 \mathrm{U}$ Colo L Rev (forthcoming 2008) (available online at http://works.bepress.com/cgi/viewcontent.cgi?article $=1005 \&$ context $=$ shi_ling_hsu), for a discussion of the formidable obstacles to such lawsuits being successful.
} 
California Attorney General against six large automobile manufacturers on political question grounds. ${ }^{151}$ The decision generally followed the reasoning of Connecticut $v$ American Electric Power. In August 2007 a Mississippi federal district court also cited the political question doctrine as an alternative ground for rejecting a private tort suit against oil, chemical, and coal companies alleging that global warming exacerbated the damage caused by Hurricane Katrina. ${ }^{152}$

One preemption issue that may be resolved by the Massachusetts $v E P A$ decision is the question whether state regulation of greenhouse gas emissions is preempted by the federal Energy Policy and Conservation Act (EPCA). This argument has been the central element of the auto industry's challenge to California legislation requiring the first reductions in greenhouse gas emissions from motor vehicles. ${ }^{153}$ In 2002 the California Legislature adopted legislation requiring the California Air Resources Board (CARB) to issue "regulations that achieve the maximum feasible and costeffective reduction of greenhouse gas emissions from motor vehicles." 154 In 2004 CARB issued regulations limiting emissions of greenhouse gases from motor vehicles beginning with the 2009 model year. The regulations set limits on emissions per mile traveled and require substantial reductions in such emissions by the 2016 vehicle year. The companies argue that because the only practicable way to reduce emissions of greenhouse gases from motor vehicles is to improve their fuel economy, California's regulations should be preempted by EPCA's mandate that the Department of Transportation establish national fuel economy standards. This argument seems a bit of a stretch since the two programs were adopted for entirely different purposes-California's to combat climate change and EPCA's to reduce U.S. dependence on imported oil. In 1983 the U.S. Supreme Court held that California's moratorium on the construction of new nuclear power plants was not preempted by the federal Atomic Energy Act because it was an economic measure rather than a safety reg-

\footnotetext{
${ }^{151}$ California v General Motors Corp., 2007 WL 2726871 (ND Cal 2007).

${ }^{152}$ Comer v Murphy Oil USA, Inc., No. 05-CV-436LG (SD Miss, Aug 30, 2007) (the court also dismissed the case for lack of standing).

${ }^{153}$ Central Valley Chrysler-feep v Witherspoon, 2006 WL 2734359 (ED Cal 2006).

${ }^{154}$ Cal Health \& Safety Code $\$ 43018.5$ (West 2006).
} 
ulation. ${ }^{155}$ Though it is true that improving fuel economy is currently the most viable option for reducing greenhouse gas emissions from motor vehicles - in fact carbon dioxide emissions from vehicles usually are calculated by reference to vehicles' fuel economy-the different purposes of the California and federal programs should be sufficient to insulate the California regulations from preemption.

In Massacbusetts $v$ EPA the Court rejected EPA's argument that EPCA's mandate that DOT establish national fuel economy standards indicates that Congress could not have intended to give EPA the authority under the Clean Air Act to regulate greenhouse gas emissions. "The two obligations may overlap, but there is no reason to think the two agencies cannot both administer their obligations and yet avoid inconsistency." ${ }^{156}$ While not legally controlling on the state preemption question, the Court's decision already has lent strong support to the argument that Congress did not intend to preempt states from regulating greenhouse gas emissions when it adopted the EPCA. Indeed, two federal district courts already have relied on it in rejecting challenges to state adoption of California's regulations on greenhouse gas emissions from motor vehicles. ${ }^{157}$

The Court's decision that EPA acted arbitrarily and capriciously in denying the petition to regulate greenhouse gas emissions confirms the availability of judicial review for agency action refusing to initiate rulemaking. Given that the Clean Air Act specifically provides for such review, there is nothing exceptional about this aspect of the decision. By highlighting the legal risk an agency incurs when it formally denies a petition for rulemaking, the decision may give agencies even more incentive to let such petitions languish unanswered, particularly since courts generally tolerate lengthy delays when litigation is brought to compel a response.

While decisions not to initiate rulemaking generally are treated with great deference by reviewing courts, as the majority recognized, if the Court had accepted EPA's rationale for refusing to act it would be exceedingly easy for any agency in the future to

\footnotetext{
${ }^{155}$ Pacific Gas \& Electric v State Energy Resources Conservation and Development Commission, 461 US 190 (1983).

${ }^{156} 127$ S Ct 1438, 1462 (2007).

${ }^{157}$ Green Mountain Chrysler Plymouth Dodge Jeep v Crombie, 508 F Supp 2d 295 (D Vt 2007); Central Valley Chrysler-feep, Inc. v Goldstone, 2007 WL 4372878 (ED Cal 2007).
} 
justify such a refusal. By requiring EPA to base its decision only on statutorily relevant factors, the Court denies the agency the option of manufacturing virtually universally applicable excuses for inaction. Faced with an undoubtedly serious problem and a comprehensive statutory scheme capable of responding to it, the Court refused to allow the agency an easy escape valve to excuse its inaction.

The Supreme Court's decision in Massachusetts $v$ EPA profoundly surprised both EPA and the White House. After believing that the agency had successfully extricated itself from the need to develop regulations to control greenhouse gas emissions, EPA staff now are scrambling to develop expertise on the issue. But it is far from clear that the decision will spur any fundamental change in the Bush administration's approach to climate change. Six weeks after the Supreme Court's decision was released, President Bush issued Executive Order 13,432 directing EPA to cooperate with DOT and the Department of Energy before taking any action to address the problem of greenhouse gas emissions from motor vehicles. ${ }^{158}$

The climate change problem is a classic "tragedy of the commons"159 that can only be addressed effectively through global collective action. The challenge facing the nations of the world has been how to fashion an effective global response to this problem. Following the model of the successful Montreal Protocol on Substances that Deplete the Ozone Layer, 154 nations at the Rio "Earth Summit" in 1992 signed the United Nations Framework Convention on Climate Change (UNFCCC). The UNFCCC endorsed the principle of controlling emissions of greenhouse gases to prevent harm to the global environment, but it did not establish specific numeric limits or timetables for reducing emissions. This treaty was signed by President George H. W. Bush and ratified unanimously by the U.S. Senate on October 15, 1992. At the time it ratified the treaty, the United States was the fourth nation in the world to ratify the treaty, following action by three island nations. ${ }^{160}$ Today 192 nations-virtually every nation in the

\footnotetext{
${ }^{158}$ Executive Order 13,342, 72 Fed Reg 27,717 (May 14, 2007).

${ }^{159}$ Garrett Hardin, The Tragedy of the Commons, 162 Science 1243 (1968).

${ }^{160}$ Mauritius, the Seychelles, and the Marshall Islands were the first to ratify the UNFCCC. United Nations Framework Convention on Climate Change, Status of Ratification, online at http://unfccc.int/files/essential_background/convention/status_of_ ratification/application/pdf/unfccc_conv_rat.pdf.
} 
world-have ratified this treaty, which entered into force on March 21, $1994 .^{161}$

While the UNFCCC did not establish binding limits on emissions of greenhouse gases, it spawned a process of negotiations that culminated in the Kyoto Protocol in December 1997. The Protocol requires developed nations to reduce their emissions of greenhouse gases between 2008 and 2012 to achieve an overall 5 percent reduction below 1990 levels. The United States played a major role in negotiation of the Kyoto Protocol, which was signed by President Clinton, but never submitted to the U.S. Senate for ratification. Four months before the Protocol was adopted, the U.S. Senate had passed a resolution insisting that any global scheme for controlling emissions of greenhouse gases should require developing countries to limit their emissions during the same time frame as developed countries. ${ }^{162}$ But this was rejected during the Kyoto negotiations as fundamentally unfair to the developing world because developed countries had contributed the vast majority of emissions that created the climate change problem. The ultimate understanding reached in Kyoto was that as a simple matter of fairness developed countries should take the first steps to reduce emissions of greenhouse gases and that the question of controls on emissions from developing countries would be addressed in subsequent negotiations.

During the 2000 presidential campaign George W. Bush had promised to support mandatory controls on emissions of carbon dioxide as a means for controlling climate change. But shortly after he assumed office, President Bush repudiated this campaign promise and expressly rejected the Kyoto Protocol. He did so in March 2001 immediately after his new EPA administrator, Christie Todd Whitman, had returned from her first international conference where she had assured her counterparts from other countries of the new administration's commitment to mandatory controls on carbon dioxide emissions. Five years later President Bush reportedly confided to a group of historians that he regrets the "in your face" manner in which he repudiated the Kyoto Protocol as "too abrupt, too defiant and too negative without offering an al-

\footnotetext{
${ }^{161} \mathrm{Id}$.

${ }^{162}$ S Res 98, 105th Cong, 1st Sess (July 25, 1997).
} 
ternative." ${ }^{163}$ But his administration has consistently taken the position that the Kyoto Protocol is fatally flawed because it does not require developing countries to control their emissions.

While the Bush administration initially believed that it could block the Kyoto Protocol from entering into force, virtually every country other than the United States and Australia ratified it. As a result, the Protocol entered into force on February 16, 2005. At the time of its entry into force, many U.S. business leaders were quoted as saying that it was inevitable that the United States ultimately would have to adopt mandatory controls on greenhouse gas emissions. But the Bush administration has continued to oppose all proposals for regulating greenhouse gas emissions. Because the United States has been the largest emitter of greenhouse gases in the world, its continued refusal to agree to such controls has provided convenient cover for developing countries to refuse to adopt such controls. While China is now poised to pass the United States as the largest emitter of greenhouse gases, it has contributed a much smaller cumulative share of historical emissions and its per capita emissions are still only about one-fifth those of the United States.

As scientific evidence continues to mount that climate change is occurring at an even more alarming rate than previously anticipated, U.S. opposition to mandatory controls on greenhouse gas emissions has become an increasingly isolated position. In November 2007 Australian voters elected a new Prime Minister who made ratification of the Kyoto Protocol his first priority. As a result, at the most recent Conference of the Parties to the UNFCCC, held in Bali in December 2007, the United States was the only developed country that continued to oppose mandatory controls on greenhouse gas emissions. U.S. environmentalists assured representatives from other countries that the U.S. position would change after the presidential election of 2008, and they noted that states containing more than 40 percent of the U.S. population were adopting their own controls on greenhouse gas emissions. The Supreme Court's Massachusetts v EPA decision also was cited as increasing the prospects for federal regulation in the United States. The United States ultimately joined the other nations of the world in adopting the "Bali Action Plan," which

${ }^{163}$ Peter Baker, In Bush's Final Year, the Agenda Gets Greener, Wash Post A1, A10 (Dec 29, 2007). 
recognizes "that deep cuts in global emissions will be required to achieve the ultimate objective of the [UNFCCC]" and establishes a process for negotiating a post-Kyoto control plan. ${ }^{164}$

Following the conclusion of the Bali conference, the U.S. Congress enacted compromise energy legislation that requires new motor vehicles sold in the United States to achieve an average of thirty miles per gallon by the year 2020, a 40 percent improvement over current fuel economy standards. ${ }^{165}$ President Bush agreed to sign the legislation, noting that he had endorsed a goal of reducing U.S. gasoline consumption by 20 percent over the next decade during his January 2007 State of the Union message. ${ }^{166}$ Hours after President Bush signed the legislation on December 21, 2007, EPA Administrator Steve Johnson stunned the states and the environmental community by announcing that he was denying California's request for permission to put its controls on greenhouse gas emissions from motor vehicles in effect, effectively vetoing control schemes adopted by seventeen states. ${ }^{167}$ His action represented the first time in the history of the Clean Air Act that California had been denied approval to adopt an air pollution control standard more stringent than the federal government. California's fifty previous waiver requests had been routinely granted.

Administrator Johnson argued that the new energy legislation represented a "national approach to addressing the problem of climate change" that would be preferable to a "patchwork" of state standards. But the new energy legislation was never intended to represent a national response to climate change. Its requirements are not as stringent as the California plan, the adoption of which could not create any "patchwork" because the Clean Air Act requires states other than California either to follow the national standard or standards identical to the California plan. Johnson argued that because of "the global nature of the problem of climate change" California did not have a "need to meet compelling and

\footnotetext{
${ }^{164}$ Conference of Parties to the UNFCCC, COP 13, Bali Action Plan, online at http:// unfccc.int/files/meetings/cop_13/application/pdf/cp_bali_action.pdf.

${ }^{165}$ President Bush Signs H.R. 6, the Energy Independence and Security Act of 2007 (Dec 19, 2007), online at http://www.whitehouse.gov/news/releases/2007/12/20071219-6.html.

${ }^{166}$ See 2007 State of the Union Policy Initiatives (Jan 23, 2007), online at http://www .whitehouse.gov/stateoftheunion/2007/initiatives/sotu2007.pdf.

${ }^{167}$ EPA Newsroom, America Receives a National Solution for Vebicle Greenhouse Gas Emissions (Dec 19, 2007), online at http://yosemite.epa.gov/opa/admpress.nsf/d0cf6618525 a 9 efb85257359003fb69d/41b4663d8d3807c5852573b6008141e5!OpenDocument.
} 
extraordinary conditions," 168 quoting the statutory standard governing California waiver requests in $\$ 209$ of the Clean Air Act.

EPA's action was widely denounced as arbitrary and capricious and contrary to law. California Governor Arnold Schwarzenegger vowed to sue to overturn it. ${ }^{169}$ An editorial writer deemed it particularly hypocritical since EPA previously had praised California's program to control greenhouse gas emissions when reporting to the international community on the nation's progress in responding to climate change. ${ }^{170}$ It quickly leaked that EPA staff had opposed the decision and advised Administrator Johnson that it would be overturned in court. The hasty announcement of the decision and EPA's tortured attempt to link it to the just-signed energy legislation suggests that its rationale rests largely on political, rather than carefully considered legal grounds.

Through its decision in Massachusetts $v E P A$, the U.S. Supreme Court briefly joined the mounting global forces pushing for regulatory action to control emissions of greenhouse gases. While the Bush administration's policy has seriously jeopardized the difficult quest for a collective global response to this critical problem, actions by U.S. states to fill the gap left by federal inaction have provided some hope to the rest of the world. EPA's decision to veto state controls on emissions from motor vehicles represents a severe setback, but one that may be quickly overturned in court.

\section{Conclusion}

A century ago, the U.S. Supreme Court recognized that it had a duty to respond to states seeking relief from serious harm caused by pollution originating outside their borders. In a series of cases spanning several decades, the Court used the common law of nuisance to issue injunctions limiting air pollution from smelters and requiring cities to construct sewage treatment plants and garbage incinerators and to stop practices that caused visible environmental harm to neighboring states. ${ }^{171}$ The Court even-

\footnotetext{
${ }^{168}$ Letter from EPA Administrator Stephen Johnson to California Gov. Arnold Schwarzenegger (Dec 19, 2007), online at http://www.epa.gov/otaq/climate/20071219-slj.pdf.

${ }^{169}$ Press Release, Governor Schwarzenegger Issues Statement After U.S. EPA Rejects California's Tailpipe Emissions Waiver Request (Dec 19, 2007), online at http://gov.ca.gov/index.php?/press-release/8353/.

${ }^{170}$ Arrogance and Warming, NY Times A38, Dec 21, 2007.

${ }^{171}$ Georgia v Tennessee Copper Co., 237 US 474 (1915); Wisconsin v Illinois, 281 US 696 (1930); New Jersey v City of New York, 284 US 585 (1931).
} 
tually abandoned this role after Congress adopted comprehensive regulatory programs to protect the environment. A key element of nearly all these programs are citizen suit provisions designed to ensure that the agencies charged with protecting public health and the environment perform their duties in implementing and enforcing the law.

Today the Court is badly split in its approach toward these regulatory programs and the role of the judiciary in ensuring their implementation. Four Justices recognize the importance of these programs and the need for them to be able to adapt to newly discovered environmental problems not fully anticipated when the underlying regulatory legislation was adopted. Four other Justices are openly hostile toward these programs and seek to limit their reach by approaching them through the traditional paradigm of private law litigation. The latter advocate narrow constructions of the scope of federal regulatory authority and they seek to limit the ability of citizens to enlist the judiciary in ensuring that agencies act in conformity to law. The man in the middle-Justice Kennedy—straddles both camps. In Massachusetts $v$ EPA he joined the four Justices sympathetic to precautionary regulation to hold that the Clean Air Act authorizes EPA to regulate greenhouse gas emissions and to recognize the standing of states to force EPA to reconsider its refusal to adopt such regulations. As a result, the Court has now stepped in to nudge the executive to use its regulatory authority to respond to the most serious environmental issue of our time.

While this decision is a landmark victory for environmentalists, it also confirms just how sharply divided the Court is on virtually all aspects of its approach to regulatory policy. The Justices hostile toward federal regulatory programs appear to be influenced by common law notions that judicial intervention is unwarranted in the absence of individualized proof of causal injury. Yet the inadequacies of the common law in protecting the environment were a major reason why Congress adopted regulatory programs and the comprehensiveness of these programs is the reason why the Court found them to preempt federal common law.

Due to the enactment of comprehensive regulatory legislation, the common law no longer serves as the first line of defense for public health and the environment. Instead, it functions largely as a backstop to respond to problems not adequately dealt with by 
precautionary regulation. The petition seeking EPA regulation of greenhouse gases that was the focal point of the litigation in Massachusetts $v E P A$ is only one of a series of legal initiatives to respond to climate change. Because the United States has refused to regulate emissions of greenhouse gases, nuisance litigation has resurfaced as a vehicle for responding to this problem.

While the Court's decision may help plaintiffs establish standing premised on the harms caused by climate change, it is still unlikely that nuisance litigation directed at this problem will be successful. Unlike the harm caused by the copper smelters in Georgia $v$ Tennessee Copper, the century-old precedent on which the Massacbusetts $v E P A$ Court relied for its standing analysis, the causes and consequences of climate change are truly global in scope. Massachusetts $v E P A$ confirms that it is not necessary to tackle the entire problem at once in order to seek judicial redress. Its "every little bit helps" approach is consistent with what the plaintiffs in Connecticut $v$ American Electric Power are seeking-modest reductions in emissions of greenhouse gases from the defendant utilities. Indeed, this is essentially what the Supreme Court ultimately mandated in Tennessee Copper-modest emissions reductions that did not threaten the economic viability of the enterprises, but which helped spur the development of new pollution control technology. ${ }^{172}$ Although the U.S. Supreme Court's decision in Tennessee Copper ultimately resulted in an injunction that limited emissions from a copper smelter, the initial emissions limits were set at a level that did not threaten the economic viability of the company. But the threat of future liability and particularly the uncertainty concerning the ultimate remedy to be applied by courts in abating nuisances helped encourage the companies to develop new technology.

Like the litigation in Georgia $v$ Tennessee Copper a century ago, Massachusetts $v E P A$ should spawn renewed efforts to confront a widely acknowledged environmental problem that no court could possibly hope to solve by itself. In the face of what many believe to be the most widespread and serious environmental problem humans face, the Court has taken a modest step to enter the

${ }^{172}$ See Robert V. Percival, Resolución de Conflictos Ambientales: Lecciones Aprendidas de la Historia de la Contaminación de las Fundiciones de Minerales, in Alejandra Quezada Apablaza, ed, Prevención y Solución de Conflictos Ambientales: Vias Administrativas, furisdiccionales y Alternativas 399, 407-17 (LexisNexis, 2004). 
vacuum left by executive inaction. Like its decision a century ago in Tennessee Copper, the Court's Massachusetts v EPA decision is a victory for states seeking federal help to begin the long process of combating a problem that extends beyond their jurisdiction. With its decision in Massachusetts v EPA the Court returns in part to the role it played in the early twentieth century by forcing action, at the behest of a state, when no other federal institution was responding to a serious environmental problem.

Massachusetts $v$ EPA does not herald a new age of judicial activism to protect the environment. The sharp dissents on standing and the merits joined by the four dissenting Justices are a reminder that the Supreme Court remains as sharply divided as humanly possible on crucial issues of environmental law. By joining the dissenting Justices in Massachusetts $v E P A$ and the plurality in $R a$ panos the two newest members of the Court-ChiefJustice Roberts and Justice Alito-confirm that they, along with Justices Scalia and Thomas, are highly skeptical of federal environmental regulation. Their views on standing to sue in environmental cases clearly represent a shift in a more restrictive direction away from the views of the Laidlaw majority that included both of their predecessors, Chief Justice Rehnquist and Justice O'Connor. Thus, for now, the shadow cast by the common law approach to judicial review of regulatory decisions has grown and the fate of most environmental litigants before the Court remains firmly in the hands of a single Justice-Justice Kennedy.

In Massachusetts $v$ EPA the Court emerged from the growing shadow of the common law paradigm to produce a truly remarkable decision. The decision, and the unusual efforts by U.S. states to address a global problem, have rekindled hopes for the ultimate development of a global consensus approach for responding to climate change, despite the Bush administration's continuing opposition. EPA's decision to deny California's request for approval of its program of state controls indicates that careful judicial scrutiny of agency action must continue to ensure that the environmental laws are used appropriately in addressing the most serious environmental problem of our time. 